\title{
«LA CIUDAD DE NUESTRA CONCIENCIA»: LOS CONVERSOS Y LA CONSTRUCCIÓN DE LA IDENTIDAD JUDEOCRISTIANA (1449-1556)*
}

\author{
POR \\ MARÍA LAURA GioRDANO \\ Universitat Abat Oliba-CEU
}

\section{RESUMEN}

La construcción de la identidad cristiana de los judeoconversos fue un proceso que se desarrolló paralelamente con la creación de un perfil de heterodoxo, sospechoso en la fe, asociado desde entonces a la imagen del converso. Un proceso que en buena parte puede ser descrito como un remar contracorriente, mientras la Inquisición convertía al «cristiano nuevo» en el paradigma del hereje del siglo XVI.

El trabajo de intelectuales como Alonso y Teresa de Cartagena no se limitó a responder a los ataques de quienes no querían que los conversos entraran en la «ciudadela» cristiana. Ellos, de hecho, ayudaron a su gente a encontrar una identidad cristiana en su historia y en un peculiar estilo de cristianismo que les distinguió de los «cristianos viejos»: el de la espiritualidad interior y del iluminismo paulino. La prueba de que no fue una labor aislada de unos pocos intelectuales y humanistas del siglo XV la encontramos en la figura de Juan de Ávila. Un siglo después, el Apóstol de Andalucía hace del paulinismo un lenguaje espiritual que es ya todo un código para sus lectores y discípulos.

Uno de los aspectos en común entre los Cartagena y Juan de Ávila es la vibrante conciencia de pertenecer a la «otra orilla del cristianismo», formada por los críticos de la Inquisición y de la mentalidad de la «limpieza de sangre».

* Este estudio se ha podido realizar gracias a la financiación de la Fundación Caja Madrid, que me concedió un beca posdoctoral para desarrollar el proyecto de investigación «Converso y Patronazgo: el caso de Teresa de Cartagena» durante los años 2004-2006. 
Al paulinismo, Juan de Ávila añadió su reflexión sobre el concepto de «beneficio de Cristo», otra monumental contribución de los conversos al pensamiento cristiano.

PALABRAS ClAVE: Conversos, Inquisición, limpieza de sangre, identidad, religión, cristianismo, literatura espiritual.

\title{
«LA CIUDAD DE NUESTRA CONCIENCIA»: THE CONVERSOS AND THE CONSTRUCTION OF THE JUDEOCONVERSO IDENTITY (1449-1556)
}

\begin{abstract}
The construction of Christian identity by Judeo-conversos was a process that developed parallel to the creation of the character of a heretic whose faith was suspect, associated from that moment with the image of the converso. It was a process that in large part could be described as rowing against the current, while the Inquisition converted the «cristianos nuevos» into the paradigm of heresy in the $16^{\text {th }}$ century.

The work of intellectuals like Alonso and Teresa de Cartagena was not limited to responding to the attacks of those who did not want the conversos entering into the Christian «citadel». In fact, they helped their people to construct a Christian identity through their history and the peculiar style of Christianity, that distinguished them from the «cristianos viejos»: that of an interior spirituality and of a «iluminismo paulino».

The proof that this was not the isolated work of few intellectuals and humanists of the $15^{\text {th }}$ century is found in the figure of Juan de Ávila. A hundred years later, Juan de Ávila's Paulinism created a spiritual language that became a code communicating with his readers and followers.

One of the most important aspects that the Cartagenas and Juan de Ávila held in common was a vibrant awareness of pertaining to the «other shore of Christianity», formed by those critical with the mentality of «limpieza de sangre» and the Inquisition.

Ávila added to the Paulinism his reflexions on the concept of the «beneficio de Cristo», another monumental contribution by the conversos to the Christian thought in the Modern Age.
\end{abstract}

KEY WORDS: conversos, Inquisition, «limpieza de sangre», identity, religion, Christianity, spiritual literature.

Recibido/Received 31-07-2009

Aceptado/Accepted 29-12-2009

\section{INTRODUCCIÓN}

En 1520, en su tratado «La libertad del cristiano», Martín Lutero ofreció una de sus interpretaciones más afortunadas de las epístolas paulinas: «Tene-

Hispania Sacra, LXII

125, enero-junio 2010, 43-91, ISSN: 0018-215-X 
mos que pensar que el cristiano consta de dos naturalezas, la espiritual y la corporal. Atendiendo al alma, es denominado hombre espiritual, nuevo, interior. Se le llama hombre corporal, viejo y exterior en relación con la carne y la sangre». ${ }^{1}$

Esculpió así algunos de los conceptos clave de la Reforma: los «hombres viejos», vinculados al pasado, representado por la ley mosaica, no conocían la fuerza redentora de la fe de los «hombres nuevos». Estos últimos, liberados por la ley de la gracia, renacían como «hombres interiores»o «espirituales».

Marcel Bataillon, en Erasmo y España, demuestra que estos conceptos abrieron un nuevo universo espiritual que pronto fue compartido por Erasmo y, gracias a él, por esa inquieta minoría de españoles que conectaron con su pensamiento y sus obras. Pese a las diferencias entre el holandés y el fraile agustino, les unía un humanismo cristiano basado en una nueva idea de hombre y de fe. La novedad consistió en proclamar la liberación del cristiano de todas las servidumbres, incluida la de las obras, operada por la fe en Cristo. Este giro copernicano introdujo una nueva ética y nuevas formas de piedad: un auténtico «explosivo dentro de la petrificada armazón de la Iglesia».2

Bataillon, en la famosa carta abierta a Américo Castro, glosaba algunas de sus obras y compartía con él la potencia explicativa del «complexe cristianos, moros y judíos» como eje fundamental de la «originalidad» española. ${ }^{3}$ Sin embargo, a diferencia de este último, vinculó esa «originalidad» a los dinamismos históricos más que a «des caractères permanents» $\mathrm{o}$ «une fois pour toutes donnés». ${ }^{4}$

Por esta razón replicó a Castro, empeñado en sustanciarla en un «más allá», sustrato de todas las ansias vitales de lo hispánico, con esta fórmula: para Bataillon, la «originalidad» de la España religiosa latía en la tensión excepcional entre la religión exterior, «volontiers idolâtrique, de la masse», y la interior, «rigoureusement christocentrique, d'une minorité».5

La horizontalidad de Bataillon, con su buceo sincrónico en la historia cultural buscando las resonancias hispanas de la philosophia Christi, ha permitido

\footnotetext{
${ }^{1}$ M. LutERo, «La libertad del cristiano», en Obras, T. EgIDo (ed.), Ediciones Sígueme, Salamanca, 1977, p. 157.

2 Américo CAStro, «Lo hispánico y el erasmismo», Revista de Filología Hispánica, II (1940), p. 2.

3 Marcel Bataillon, «L'Espagne religieuse dans son histoire», Bulletin Hispanique, LII (1950), pp. 5-26.

En este estudio, Bataillon hacía referencia a las siguientes obras de Castro: España en su historia: Cristianos, moros y judíos, Buenos Aires, 1948; Aspectos del vivir hispánico: espiritualismo, mesianismo, actitud personal en los siglos XIV al XVI, Santiago de Chile, 1949; «Lo hispánico y el erasmismo», Revista de Filología Hispánica, op. cit.; «El enfoque histórico y la no hispanidad de los visigodos», Nueva Revista de Filología Hispánica, III (1949), pp. 217-263.

${ }^{4}$ Ibidem, pp. 16 y 19.

5 Ibidem, p. 19.
} 
medir el peso del erasmismo en la península. Desde allí las primeras sospechas: su arraigo fue tan hondo que no podía tratarse únicamente de un fenómeno de importación. El paso siguiente fue reconocer que su historia se cruzaba con la de los conversos, quienes habían operado "par leur seule présence une rénovation du christianisme espagnol» ${ }^{6}$

$\mathrm{Su}$ elemento vertebrador fue el humanismo paulino. Cuando apareció en Castilla, alrededor de ochenta años antes de Lutero, conquistó las mentes de los cristianos nuevos y se apoderó de su léxico espiritual.

De ahí la necesidad de reescribir la historia religiosa española del siglo XVI teniendo en cuenta el atormentado siglo XV y «la spiritualité de l'élite juive avant la conversion». ${ }^{7} \mathrm{~A}$ este propósito, Bataillon reprochaba sutilmente a Castro haber descuidado dentro de su obra «l'apport posif» de los conversos a la historia de España. ${ }^{8}$

A lo largo del siglo $\mathrm{XV}$, siempre que se desarrollaba un debate religioso había también una conciencia conversa inquieta que acudía a la autoridad del apóstol Pablo, como el navegante cuyo barco ha perdido el rumbo en la noche oscura. Más adelante, ya asentados en el cristianismo, volvieron a protagonizar el debate religioso inevitablemente, puesto que entonces su formación y vivencia paulina les puso en sintonía directamente con el contexto europeo y, sobre todo, con lo que de dicho contexto penetró en España gracias a Erasmo.

Hoy sabemos que allí la «religión interior» tuvo una historia previa a Lutero y también a la exitosa penetración del erasmismo. Buena prueba de ello la encontramos en la primera mitad del siglo XV: antes de nacer el reformador alemán, el obispo de Burgos, el converso Alonso de Cartagena, escribió un tratado espiritual sobre el «hombre exterior» y el «hombre interior» y sobre la fe como «iluminación» o gracia divina, e incluso llegó a prefigurar la «oración mental».

¿Cómo podemos explicar una tan precoz maduración respecto a los tiempos europeos de la Reforma?

El caso de Alonso de Cartagena no fue el único; como veremos, los conversos fueron el elemento «acelerador» de la historia espiritual española. Por esta razón, estudiar el «complejo judeocristiano» requiere antes que nada asumir el desfase que esto produjo en ella respecto a los movimientos de renovación europeos, como la devotio moderna o la rebelión luterana.

Un desfase que, además, pone en evidencia la aportación relevante pero absolutamente tardía del erasmismo a todo ese movimiento que Bataillon denomi-

\footnotetext{
6 Ibidem, p. 23.

7 Ibidem, pp. 21-22.

${ }^{8}$ Ibidem, p. 23.
} 
nó Reforma. De hecho, el paulinismo de Erasmo pudo triunfar porque se injertaba en un paulinismo anterior.

Por otra parte, el vínculo con las ideas y movimientos ultra pirenaicos fue asegurado por el iluminismo, sin el cual no se entiende el papel de España en la historia europea del siglo XVI. ${ }^{9}$

En definitiva, descubrir el carácter de la experiencia religiosa de los conversos en el siglo XV equivale a encontrar las raíces mismas de la Reforma y a dar cuenta finalmente de su «aportación positiva» a la España cristiana. He aquí el objetivo de este estudio.

\section{9: ANNUS TERRIBILIS}

E1 27 de enero de 1449 en la ciudad de Toledo un grupo de hombres saquearon y quemaron la casa de Alfonso Cota, recaudador de impuestos converso. Fue la primera chispa de un levantamiento popular contra la política del favorito de Juan II de Castilla, don Álvaro de Luna, a quien se acusaba de ayudar a los cristianos nuevos para hacerse con el gobierno la ciudad. Desde que el 2 de mayo los rebeldes expresaron estas acusaciones en una Suplicación a aquel soberano, ${ }^{10}$ la cuestión conversa no sólo se puso sobre la mesa, sino que se «instaló en la primera línea de la política interior de la nación». ${ }^{11}$

En su mayoría expresión del patriciado urbano, los cristianos nuevos de Toledo fueron acusados de haber expoliado sistemáticamente las tierras y las riquezas del Reino durante el ejercicio de sus oficios. Se afirmó públicamente que habían usurpado el poder de la nobleza y habían fingido la conversión al cristianismo como parte de una táctica para mantener su posición económica y acrecentar sus bienes, mientras seguían practicando el judaísmo y planeaban arruinar las vidas de los cristianos viejos. Como una gran telaraña que se iría

\footnotetext{
9 Ibidem, p. 20.

10 «Por quanto es notorio que el dicho don Álvaro de Luna, vuestro condestable, públicamente à defendido e rreçebtado e defiende e rreçebta a los conversos de linaje de los judíos de vuestros señoríos e rreynos, los quales por la mayor parte son fallados ser ynfieles e herejes; e han judayzado e judayzan, e han guardado y guardan los más dellos los rritos e ceremonias de los judíos, apostando la crisma e vautismo que rreçeuieron, demostrando por las obras e palabras que lo rrescebieron en el cuerpo y non en los coracones ni en las voluntades, a fin que so color e nonbre de crisitanos, prebaricando, estroxesen las ánimas e cuerpos e faziendas de los cristianos viejos...». Este documento, redactado por Pedro Sarmiento, repostero mayor del rey, y por otros miembros de la ciudad de Toledo, ha sido publicado por J. Mata CARriazo (ed.), Crónica del Halconero de Juan II, Pedro Carrillo de Huete, Espasa Calpe, Madrid, 1946, pp. 520-526.

11 B. Netanyahu, Los orígenes de la Inquisición en la España del siglo XV, Crítica, Barcelona, 1999 , p. 320.
} 
extendiendo paulatinamente, su influencia llegaría a cubrir todas las posiciones de poder del reino. El propósito de los rebeldes fue, por tanto, desmantelar la burocracia de la administración real y restituir el poder al pueblo. El proceso de desintegración social irreversible que desencadenó hizo de esta «primera expresión pública del sentimiento anticonverso» un evento histórico. ${ }^{12}$

A la Suplicación le siguió un mes más tarde otro decreto oficial contra los conversos, la Sentencia-Estatuto, un documento que ya proclama el rasgo que desde entonces, y durante los siguientes siglos de la Edad Moderna, pesará sobre los cristianos nuevos: el de ser «sospechoso en la fe». ${ }^{13}$ Directamente relacionado con este estigma aparecía otro, que fusionaba la engañosa identidad religiosa con el «perverso linaje de los judíos». ${ }^{14}$ Basándose en estas acusaciones, se prohibía a los conversos desempeñar «todo oficio y beneficio público y privado», así como testificar en tribunales públicos.

Se empezó adoptando una medida para entorpecer una integración que parecía posible, mientras se estrenaba una palanca ideológica apta para eliminar toda una clase de funcionarios y letrados de ascendencia judaica que habían ocupado amplios sectores de la administración civil, sobre todo en sus ramificaciones municipales. ${ }^{15}$

Se había sembrado, pues, una semilla de odio de la que brotó todo un movimiento anti-converso, alimentado durante siglos por «la letra y el espíritu del Estatuto de Toledo». ${ }^{16}$ Sería un error, sin embargo, dar crédito al mensaje de los rebeldes toledanos e imaginar a los judeo-conversos como a un grupo separado de los demás en el interior de la Castilla del siglo XV. Al contrario, estuvo tan bien integrado en la sociedad de su tiempo que era imposible llevar a cabo un programa de discriminación en su contra sin involucrar a todos los demás. Las raíces judías eran fuertes sobre todo entre los nobles, que, por formación y prestigio social, representaban el corazón latente de la cultura y del poder de Castilla en esos años. Esto opinaba el converso Fernán Díaz de Toledo, un influyente

12 Ibidem, p. 330. «Más aún, fue la primera posición oficial adoptada con respecto a los conversos y a la cuestión conversa por un grupo organizado del pueblo español. (...) Ante todo, fue la salva inicial de un movimiento, que culminaría en la fundación de la Inquisición española y por ella se convertiría en una fuerza destinada a influir en el curso de la historia universal».

${ }^{13}$ Cfr. «Sentencia que Pedro Sarmiento, asistente de Toledo, y el Común de la Ciudad dieron en el año 1449 contra los Conversos». El texto de este documento ha sido publicado por M. Alonso como apéndice a Alonso de Cartagena, Defensorium unitatis christianae, CSIC, Escuela de Estudios Hebraicos, Madrid, 1943, pp. 357-365.

14 Ibidem, p. 362.

${ }^{15}$ Cfr. Francisco Márquez Villanueva, «Conversos y cargos consejiles en el siglo XV», Revista de Archivos, Bibliotecas y Museos, 63 (1957), pp. 503-540 y ahora en I., De la España judeoconversa. Doce estudios, Edicions Bellaterra, Barcelona, 2006, pp. 137-174.

${ }^{16}$ B. Netanyahu, Los orígenes de la Inquisición en la España del siglo XV, op. cit., p. 346. 
y poderoso letrado de la corte de Juan II, autor de una de las respuestas más eficaces a la Sentencia-Estatuto, ${ }^{17}$ la Instrucción del Relator. ${ }^{18}$

Como reacción a dicho escrito y a las bulas pontificias en favor de los conversos del 24 septiembre de 1449,19 el bachiller Marcos García de Mora, principal ideólogo e instigador del grupo de los rebeldes toledanos, redactó poco después un Memorial. Se trata de un panfleto en contra de los conversos y sus fautores,${ }^{20}$ cuya principal característica es ser un catálogo de descalificaciones, insultos y acusaciones, rebosantes de rabia visceral, con las que el autor pretendía justificar las violentas iniciativas de los revoltosos.

Pero aún hay más. El bachiller García de Mora elaboró una teoría según la cual los cristianos nuevos, por descender de los judíos -linaje «dañado» y perverso-, rechazaban el cristianismo y por ello no podían aspirar a estar en el plan de salvación de Dios. Basándose en la supuesta existencia de un complot, según el cual los conversos estaban usurpando las posiciones de los cristianos viejos y aspiraban a apoderarse del control del poder real en Castilla, se daba pública expresión a unas ideas que alcanzarán la dimensión de una creencia colectiva tenaz y duradera. En definitiva, el problema converso acababa de nacer y el bachiller García ya tenía una solución, que él mismo aplicó y luego defendió en su escrito: la matanza masiva de los conversos. ${ }^{21}$

Como es sabido, la elite intelectual de los cristianos nuevos de entonces se movilizó para rebatir los argumentos de la Suplicación y las medidas propuestas en la Sentencia-Estatuto, coronadas con el armazón ideológico del Memorial. Entre los ilustres defensores de la causa conversa destacaron personalidades de primer orden en la vida de la Iglesia: así, el cardenal teólogo del papa,

\footnotetext{
17 Nicholas G. Round, «Politics, style and group attitudes in the Instrucción del Relator», Bulletin of Hispanic Studies, vol. XLVI (1969), pp. 289-319.

${ }^{18}$ Como el texto de la Sentencia-Estatuto, también la «Instrucción del Relator para el obispo de Cuenca, a favor de la nación Hebrea» ha sido publicada como apéndice al Defensorium unitatis christianae, op. cit., pp. 343-356.

${ }^{19}$ Cfr. Vicente Beltrán DE Heredia, «Las bulas de Nicolás V acerca de los conversos de Castilla», Miscelánea Beltrán de Heredia, tomo I, Salamanca, Biblioteca de Teólogos Españoles, vol. 25, 1971, pp. 387-402.

${ }^{20}$ Eloy Benito Ruano, «El Memorial contra los conversos del bachiller Marcos García de Mora («Marquillos de Mazarambroz»), Sefarad, 1(1957), pp. 314-351 y más recientemente en I., Los orígenes del problema converso, Real Academia de la Historia, Madrid, 2001, pp. 103-140,

${ }^{21}$ Ibidem, pp. 118-119: «Por ende, si nos, los toledanos queremos ser victoriosos y que nuestra victoria Dios publique ante las gentes, devemos de acavar de perseguir aquella xeneraçión y entonçes por Espíritu de Dios entenderán todos que nuestros movimientos fueron justos y santos como los son; en otra manera siempre abrá algunas opiniones. Síguese pues que no puede ser imputado a crimen lo echo cerca de la toma de los dichos bienes, salvo lo no echo, para lo qual ay remedio, que lo acavemos de perseguir y entonces nuestros actos e movimientos serán gratos e apaçibles ante conspectum Domini y ante las gentes».
} 
Juan de Torquemada, ${ }^{22}$ el obispo de Cuenca, Lope de Barrientos, y el obispo de Burgos, Alonso de Cartagena, trabajaron activamente para replantar la «diversidad» conversa en tierra cristiana, ${ }^{23}$ especialmente Alonso de Cartagena, en quien se centra el presente estudio.

La lectura de dos escritos -uno poco conocido, la glosa al salmo «Judica me Deus» de Alonso de Cartagena, y otro muy estudiado en los últimos años, la Arboleda de los enfermos, de su sobrina Teresa de Cartagena- nos introduce en una perspectiva nueva, alejada del gran debate público que surgió a raíz del ataque anti-converso de 1449.

Los dos textos representan, por su tono coloquial e íntimo, una producción menor en cuanto a su eco en la sociedad, pero no en cuanto a sus objetivos. En ellos no se trató de demostrar la incongruencia doctrinal y el vacío argumental de las acusaciones de sus enemigos -lo que ya había sido el reto de prelados como Torquemada, Barrientos y el propio Cartagena-, sino de empezar un lento y porfiado trabajo de deconstrucción de la imagen del converso tal y como se había configurado en los escritos de los rebeldes toledanos y retroalimentado en la literatura antijudía.

${ }^{22}$ El cardenal dominico Juan de Torquemada era considerado «el mayor teólogo del siglo». A este prelado, cuya autoridad doctrinal era incuestionable, se remitían todos los asuntos más delicados y transcendentes en la Curia romana. Su Tractatus contra Madianitas et Ismaelitas sirvió de base a Nicolás V para preparar la bula del 1449 «Humani generis inimicus» en la que el pontífice tomó posición respecto a los desordenes toledanos de la pasada primavera, manifestándose a favor de los conversos. Cfr. a este propósito, Nicolás LóPEZ MARTínez, «Teología española de la convivencia a mediados del siglo XV», Burgense, 8 (1967), pp. 59 y ss. En el escrito de Torquemada no se oculta cierto clima de guerra, como evidencia el mismo título, en el que se hace referencia a los antiguos enemigos del pueblo de Dios. En el incipit, los versos del Salmo 82, 3-5 hacen presente una amenaza mortal de la cual urge defenderse: «Pues ves que tus enemigos están rugiendo; y los que te aborrecen, alzaron la cabeza. Sobre tu pueblo han tenido designos maliciosos y han maquinado contra tus santos. Dijeron: venid, y destruyámoslos como nación; y no haya más memoria del nombre de Israel». Torquemada, desarrollando los elementos simbólicos presentes en su apellido, se firmó como «Torre de fortaleza contra el enemigo», usando las palabras del salmo 60,4 que tomó como divisa de su escudo. Cfr. N. LóPez MARTínez y V. ProAÑo GIL (eds.), Juan de Torquemada, O.P. Tractatus contra Madianitas et Ismaelitas (Defensa de los judios conversos), Publicaciones del Seminario Metropolitano de Burgos, Burgos 1957. Para una versión castellana del texto de Juan de Torquemada véase E. BENITO RuANo, C. DEL VALLE RodríGuEZ, Y. Formetín IbÁÑez, V. Howel, J. J. Llamado GonzÁlez, A. Martínez CASAdo, E. Pérez Ferreiro, A. Velasco Delgado, Tratado contra los Madianitas e Ismaelitas de Juan de Torquemada (contra la discriminación conversa), C. DEL VALle RodríGuez (ed.), Aben Ezra Ediciones, Madrid, 2002.

${ }^{23}$ Fray Luis G. A. Getino ha editado el escrito de Lope de Barrientos, «Contra algunos zizañadores de la nación de los conuertidos del pueblo de Israel», Anales salmantinos, I, Salamanca 1927 , pp. 181-204. Véase también A. MARTínez CASADO, Lope de Barrientos: un intelectual de la corte de Juan II, San Esteban, Salamanca, 1994. Para un estudio contextualizado de las obras de Torquemada y de Alonso de Cartagena remito a B. Netanyahu, Los orígenes de la Inquisición, op . cit., pp. 358-361; pp. 381-440 y pp. 470-529.

Hispania Sacra, LXII

125, enero-junio 2010, 43-91, ISSN: 0018-215-X 
Era lo que requería un público de lectores fieles y expectantes, expropiados de su identidad de cristianos y deseosos de verse como parte de una historia y de un pueblo. Había llegado el momento de reconstruir su propia memoria, de encontrar los nexos entre pasado y presente a la luz de un nuevo desafío: reformular la idea de sí mismos lejos del repertorio cotidiano de imágenes deformadas. Entonces el pasado se convirtió en un arsenal de ideas potentes, -el pozo sin fondo de las memorias bíblicas-, mientras que el presente encontró en la promoción de la monarquía castellana su objetivo político principal.

Con una insospechable sincronía, la clase dirigente de las ciudades, formada en gran parte por conversos, iba preparando una serie de medidas que, al cabo de unos cuarenta años, llevaron a la expulsión de los judíos del reino. ${ }^{24}$ Alejar este último y decadente testimonio del propio pasado -se ha documentado ampliamente que en vísperas de la expulsión las aljamas estaban en una fase crítica- habría tenido que restar argumentos a quienes señalarían a las comunidades judías como un peligro permanente para los nuevos convertidos. Es evidente que así se desviaba hacia los judíos la rabia de los cristianos viejos. Pero tam-

\footnotetext{
24 Stephen H. HALICZER demuestra esta tesis en su artículo «The castilian urban patriciate and the jewish expulsions of 1480-92», The American Historical Review, vol. 78, 1 (feb. 1973), pp. 35-62. La expulsión de los judíos en 1492 fue el momento conclusivo de un proceso llevado a cabo por las elites dirigentes de la ciudad. En primer lugar, estas últimas, guiadas por los regidores, obstaculizaron a los corregidores, funcionarios de nombramiento regio, para así evitar tener que compartir el poder con los ejecutores de la voluntad regia, tradicionalmente benévola hacia los judíos. A partir de 1480 las ciudades comenzaron a adoptar medidas antijudías que hicieron peligrar la supervivencia económica de las aljamas. Estas medidas recuerdan las del Concilio de Basilea, que en 1434 expresó una clara voluntad de aislar a los judíos de los cristianos. Según una de las prohibiciones establecidas por aquella asamblea, los cristianos no podían prestar sus servicios a judíos, ni ser contratados como preceptores para sus hijos, ni tener contactos sociales con ellos, como participar en sus fiestas o en sus bodas, ni dirigirse a médicos judíos. Cfr., a este propósito, Solomon GRAYZEL, «Jews and the Ecumenical Councils», Jewish Quarterly Review, vol. 57, (1967), pp. 287-311.

Obedeciendo al postulado ideológico madurado en aquellos años en los escritos de prelados prestigiosos como Oropesa, que veía en el judío una amenaza permanente a la comunidad cristiana, las aljamas fueron alejadas de las ciudades. Se intentó debilitar su poder comercial prohibiendo los contactos con los cristianos; se aumentó la presión de los tributos y se recortaron los privilegios fiscales. En realidad, los judíos pagaban los impuestos pero las ciudades pedían que doblaran su contribución. Estas amenazaron a los soberanos de que les retirarían el apoyo en la guerra de sucesión y en el conflicto en contra de los moros si hubieran seguido protegiendo a los judíos. Así, todo un sistema de vida que había funcionado durante siglos vino a desplomarse. Los judíos no pudieron prestar sus servicios a la comunidad cristiana y intentaron sobrevivir en un aislamiento precario que los llevó al empobrecimiento y a una progresiva decadencia. Estas medidas en su conjunto fueron mal recibidas por los reyes católicos, que veían amenazada no sólo la supervivencia de un grupo social que al fin y al cabo era un importante contribuyente a las arcas del estado sino también de unos colaboradores a los que habían confiado el cobro de los impuestos del reino. No es casual que el último contrato para la recaudación de los impuestos fue renovado por tres años a partir del primero de enero de 1492 a Rabí Mayor, responsable de los ingresos ordinarios de la corona. Sin embargo, bajo el peso de esta presión prolongada, improvisadamente los soberanos cedieron, emanando el treinta de marzo el decreto de expulsión.
} 
bién habría que considerar otra lectura: el empuje del patriciado urbano a la expulsión de 1492 vino a sellar simbólicamente una voluntad de integración de quien estaba dispuesto a perder hasta el recuerdo visible de su origen.

Por ser una reacción «privada», por así decirlo, frente a los hechos del 1449, y a la larga cola que trajeron durante el siglo XV, escritos como el de Alonso y Teresa de Cartagena pudieron cargar con un reto inconfesable: la creación de una nueva identidad cristiana. Alonso de Cartagena, seguido por su sobrina Teresa, abrió el camino. Y poco menos de un siglo más tarde, cuando la persecución inquisitorial parecía haber silenciado todas las voces, una de las figuras más destacadas de la literatura espiritual del siglo XVI, Juan de Ávila, conectó con su auditorio con el mismo estilo alegórico y con las mismas inquietudes expresadas por los Cartagena.

\section{De la CONCIENCIA SITIADA: El SALmo «Judica Me Deus» De Alonso de Cartagena}

Alonso de Cartagena perteneció a una de las familias que más contribuyeron a la historia de la ciudad de Burgos y a la consolidación del poder monárquico en Castilla entre los siglos XV y XVI. ${ }^{25}$ Su padre, el rabino mayor Šelomó Ha Levi, convertido al catolicismo con el nombre de don Pablo de Santa María, fue privado de Enrique III, ayo del joven Juan II y obispo de Cartagena y de Burgos. Los cuatro hermanos de Alonso gozaron asimismo de fama en la ciudad, ${ }^{26}$

${ }^{25}$ Para un perfil biográfico del obispo de Burgos, véase M. MARTínez AÑ̃íBARRo, Intento de un diccionario biográfico y bibliográfico de autores de la provincia de Burgos, Junta de Castilla y León, 1993, pp. 88-115; F. CANTERA Burgos, Alvar García de Santa María y su familia de conversos. Historia de la judería de Burgos y de sus conversos más egregios, Instituto Arias Montano, Madrid, 1952; L. SERrano, Los conversos don Pablo de Santa María y don Alonso de Cartagena, obispos de Burgos, gobernantes, diplomáticos y escritores, CSIC, Escuela de Estudios Hebraicos, Madrid, 1942; Yeremy LAWRENCE, «Alfonso de Cartagena», en Michael Gerli, Medieval Iberia. An Encyclopedia, Routledge, New York, London, 2003, pp. 203-205. A propósito de su contribución a la consolidación del poder monárquico en Castilla, véase Robert BRIAN TATE, «La Anacephaleosis de Alfonso García de Santa María, Obispo de Burgos, 1435-1456», Ensayos sobre la historiografía peninsular del siglo XV, Gredos, Madrid, 1970, pp. 55-73

${ }^{26}$ Los hijos de don Pablo de Cartagena fueron cinco: Gonzalo, María, Alonso, Pedro y Alvar. Salvo el primogénito, los demás llevan el nombre de los hermanos de don Pablo. Gonzalo García de Santa María (1379 o 1380-1448), así se le denominó al primero de los hijos del prelado burgalés, fue doctor en Decretos por la Universidad de Salamanca y catedrático; intervino en 1416 en el concilio de Constanza como uno de los embajadores de Alfonso V de Aragón; fue embajador en Roma para el rey de Aragón en 1418 junto con el obispo de Girona; formó parte de la delegación castellana que participó en el concilio de Basilea en 1434. En 1426 fue trasladado a Plasencia, diócesis que ocupó durante veinte años. Su hermana, doña María de Cartagena nació en 1383, pero fue curiosamente silenciada en los testamentos familiares. Se casó con Alonso Álvarez de Toledo, contador mayor de Juan II, y fue madre

Hispania Sacra, LXII

125, enero-junio 2010, 43-91, ISSN: 0018-215-X 
aunque sin duda fue él el personaje más ilustre de la familia después de la muerte de su padre.

Nacido en Burgos entre 1385 y 1386,27 se convirtió al cristianismo en torno al año 1390 , periodo al que se remontaría también la conversión de su progenitor. De su intensa carrera eclesiástica y política sólo resumo aquí las etapas más destacadas: fue refrendario del Papa y capellán del Monarca; formó parte del Consejo de don Juan II y de la audiencia real; fue dos veces embajador del Rey de Castilla ante el soberano de Portugal y logró concertar las paces entre ellos.

Como hombre de confianza de Juan II, participó en el Concilio de Basilea en 1434. ${ }^{28}$ Allí pronunció un famoso discurso en defensa de los derechos de la Corona de Castilla frente a las pretensiones de Inglaterra, ${ }^{29}$ una memorable

del racionero de la catedral burgalesa Alonso Alvares. El cuarto hijo de don Pablo -siguió a Alonsofue el padre de Teresa, Pedro de Cartagena. En 1440, Juan II le otorgó una real licencia como su «vasallo e guarda» para la constitución de un mayorazgo, en recompensa por los «muchos e buenos y leales servicios» que los Cartagena hicieron a los «reyes de gloriosa memoria», sus progenitores y a él mismo. Instituido en 1448, el mayorazgo comprendía sus villas de Olmillos, San Pedro de Valdehumadas, San Martín, su casa en Burgos y otras propiedades. Este personaje destacó en la carrera política y militar: fue guarda del cuerpo de Juan II, regidor de Burgos, consejero de Enrique IV y de Fernando el Católico. El quinto hijo de don Pablo de Santa María fue don Alvar Sánchez de Santa María, nacido en torno a 1388. Fue hombre de confianza de Juan II -formó parte del Consejo del rey-y luego letrado al servicio del infante don Enrique. Don Pablo no le nombra en su testamento y no figura en el reparto de sus bienes. Sin embargo, su padre suplicó la piedad regia por este hijo suyo responsable de alguna grave falta que no se menciona y que explicaría tal vez su ausencia en el testamento. Cfr. F. CANTERA BURGos, Alvar García de Santa María y su familia de conversos, op. cit., pp. 409-496.

${ }^{27}$ L. SerRano, Los conversos don Pablo de Santa María y don Alonso de Cartagena, op. cit., p. 119.

${ }^{28}$ Las medidas que este concilio tomó a propósito de judíos y conversos se encuentran en su canon, aprobado el 15 de septiembre de 1434. Si, por una parte, en este documento se insistía en el cumplimiento de las leyes promulgadas en España en 1412, incluyendo las prohibiciones contra el nombramiento de judíos para los cargos públicos y a favor de su alejamiento de las residencias de los cristianos, por otra parte, se mostraba en muchos aspectos favorable a los conversos. No sólo se tutelaba la posición patrimonial de los recién convertidos sino que proclamaba su igualdad con los otros cristianos. Cfr. B. Netanyahu, Los orígenes de la Inquisición en la España del siglo XV, op. cit., pp. 247-250.

${ }^{29} \mathrm{El}$ objeto del litigio era el reconocimiento del derecho de precedencia de la silla de Castilla sobre Inglaterra en el Concilio. Aunque se trataba de una mera cuestión de ceremonial, en ella se lució el genio político de Cartagena que, «manipulando» la mitología y los hechos de la Historia Gothica y de las crónicas medievales, logró demostrar la mayor antigüedad de la monarquía castellana (Cfr. Robert BRIAn TATE, «La Anacephaleosis de Alfonso García de Santa María, Obispo de Burgos, 1435-1456», op. cit., pp. 62-63). Así Cartagena situó Castilla en el corazón de Europa, lo que reflejó la posición de real preeminencia que en esos primeros albores de la Edad Moderna mantuvo este reino en el concierto de las naciones europeas. Merece la pena resumir un fragmento de su memorable intervención. Explicando las razones de la superioridad de la corona de Castilla, el prelado burgalés afirmó que la primera tenía más tierra, más ciudades y villas que Inglaterra. Esta última gozaba de mucha menos antigüedad que la silla de Castilla, cuyo rey era descendiente directo de los reyes godos; ninguna corte era tan visitada, ni contaba con tantos nobles, prelados y muchedumbre de pueblos como la corte real de Castilla; ésta, a diferencia de la de Inglaterra, presentaba una «fermosa diferencia de las gentes» que le proporcionaban «diversas nasciones e diversos lenguages e diversas maneras de guarniciones de guerra». No 
arenga en la que Américo Castro reconoció un testimonio precoz de esos que «sintieron la necesidad de definir a España». ${ }^{30}$ Después de la insurrección anticonversa de 1449, que había originado una guerra civil en Toledo, se mantuvo al lado del Rey, a quien dirigió el Defensorium unitatis christianae, un tratado en defensa de los conversos en el que puso en juego su faceta de hombre de Iglesia. ${ }^{31}$ Apelando a la doctrina paulina del cuerpo místico, metáfora de una

podía decirse lo mismo de Inglaterra, mucho más uniforme desde el punto de vista de los pueblos que la constituían. Además, España recibió la palabra de Dios en tiempo de los Apóstoles, cuando Santiago y sus discípulos fueron allí a predicar; los señores reyes de Castilla guerrearon contra los moros sin pausa y defendieron la cristiandad de los herejes; Inglaterra, al estar apartada del continente por el mar, no estaba propiamente dentro del mundo, sino que era más bien un «arrabal» de aquel. El «Discurso sobre la precedencia del Rey Católico sobre el de Inglaterra en el Concilio de Basilea» está publicado, en su traducción castellana hecha por el mismo don Alonso, por Blanco García en La ciudad de Dios, (1894), t. XXXV, pp. 122 y sigs., y en M. Penna (ed.), Prosistas castellanos del siglo XV, Biblioteca de Autores Españoles, 116, Rivadeniera, Madrid, 1959, pp. 205-233.

Sobre el Cartagena político y jurista, véase L. Fernández GaLLARDo, Alonso de Cartagena. Una biografía política en la Castilla del siglo XV, Valladolid, 2002 y también R. SÁNCHEZ DOMINGO, El derecho común en Castilla. Comentario a la Lex Gallus de Alonso de Cartagena, Burgos, 2002.

${ }^{30} \mathrm{~A}$. CASTRO comentaba al respecto: «Para que nada falte en este primero y fidelísimo cuadro del alma hispana -diseñado por un judío- don Alonso termina su arenga, más que alegato, con un gesto de suprema arrogancia: «Non traeré otro testigo si non esta embajada que vedes, ca non suelen de regno pobre tales embaxadores salir». No creo que ningún otro pueblo de Europa haya expresado a comienzo del siglo XV una tan redonda y cabal conciencia de sí mismo. Castilla sintió la ineludible necesidad de salir al mundo (...)», I., España en su Historia. Cristianos, Moros y Judíos, Barcelona, Crítica, 2001, p. 30.

Según la interesante lectura de Bruce RosENSTOCK, Cartagena culminaría su proyecto de forjar un sentimiento de identidad nacional en 1449 escribiendo su Defensorium, donde desmontó la imagen de una nación que se veía a sí misma bajo el prisma de la «pureza de sangre». A esta contrapuso la «sangre híbrida», -ahora convertida en expresión de auténtica nobleza y virilidad-, puesto que en ella se cumplía la unión de dos linajes de Castilla, el de los judíos y el de los gentiles. «Cartagena has unsettled these cultural binarisms in order to re-imagine a national community in which hybridity is sacralized and «blood purity» is viewed as the return of the pagan past». Cfr. I., «Alonso de Cartagena: nation, miscegenation, and the jew in late-medieval Castile», Exemplaria, vol. 12, n. 1 (2000), pp. 185-204 y New men: conversos, christian theology, and society in fifteenth-century Castile, Department of Hispanic Studies, Queen Mary, University of London, 2002.

${ }^{31}$ Un testimonio del nivel del conflicto se encuentra en las palabras contundentes que Alonso de Cartagena dirige al bachiller Marcos García de Mora desde las páginas de su obra, después de haber rebatido sus argumentaciones jurídicas: «Quid ergo livore torqueris, marche, dicam tibi ut Demostenes eschini dicebat in illa oratione de qua Ieronimus meminit et si disrumparis, non mentior. Neque enim impatientie aut invidie tue exuberans habundancia veritatem notissimam propositionum mearum infringet. Volo, tamen, tibi en hoc deferre, ut non mirer si ad invidiam forsan aliquantulum provoceris, maxime quia, ut aliqui ferunt, ex infima gleba rustiacane sortis existis; parvulum namque, ut scriptura ait, occidit invidia. Hoc enim ex humana fragilitate connaturale quodam modo hominibus est, ut quemdam tactum tristitie sentiant, cum alios quos putant equales vel inferiores, exaltari divitiis aut honoribus vident, ipsis intra latebras sue paupertatis aut obscuritatis manentibus, presertim cum hoc sub temporis brevitate fieri conspiciunt...» («¿Por qué te atormentas con la envidia, Marcos? Te diré lo que le decía Demóstenes, el gentil, a Esquines en aquella arenga que recuerda Jerónimo: «aunque revientes no mentiré. Ni tu extraordinaria cantidad de intolerancia, o de envidia, debilitará la patentísima verdad de mi

Hispania Sacra, LXII

125, enero-junio 2010, 43-91, ISSN: 0018-215-X 
Iglesia que encuentra en Cristo su cabeza, Alonso de Cartagena apostaba por la unidad entre los cristianos. ${ }^{32}$ Desde aquellas páginas llevó a cabo un ataque demoledor contra la mentalidad de la «limpieza de sangre». Lo condensó en su definición de «pueblo nuevo»: una creación espiritual que anularía cualquier diferencia carnal entre «judíos» (cristianos nuevos) y «gentiles» (cristianos viejos). ${ }^{33}$ Con ello Cartagena apuntaba alto, puesto que solo partiendo de un cristianismo espiritual su reto podría ser alcanzado.

En 1443, siendo ya obispo de Burgos, promovió un sínodo que, junto con los de sus sucesores, Luis de Acuña y Pascual de Ampudia, fue parte de esa gran labor de reforma que dio a la Iglesia burgalesa una personalidad muy destacada, capaz de rechazar un siglo más tarde dos intentos de introducción de los estatutos de «limpieza de sangre».34

posición». Sin embargo, quiero que te des cuenta de esto, que no me maravillo si por ventura estás un poco inclinado a la envidia, especialmente porque, como algunos dicen, tú provienes de la más baja tierra de la clase campesina, como dice la Escritura: al insignificante le mata la envidia. En cierto modo por debilidad humana les es connatural a los hombres que experimentan cierto sentimiento de envidia cuando ven elevarse en riquezas y honores a otros, a los que ellos juzgan iguales o inferiores, quedándose ellos mismos encerrados en la cueva de su pobreza, o de su oscuridad. Sobre todo cuando ven que esto se realiza en un corto plazo...»), Alonso DE CARTAGENA, Defensorium unitatis christianae, op. cit, pp. 249-250, ahora en traducción castellana por Guillermo Verdín Díaz, Universidad de Oviedo, 1992, p. 321.

${ }^{32}$ Según el obispo de Burgos tanto los israelitas como los gentiles al entrar en la fe católica por la puerta del sagrado bautismo no persisten como dos pueblos o como dos linajes diferentes, sino que se cohesionan creando un pueblo nuevo, «Tam israelitas quam gentiles per sacri baptismatis ianuam ad fidem catholicam ingredientes non duos populos aut duas gentes diversas manere sed ex utrimque venientibus unum populum novum creari», Alonso DE CARTAGENA, Defensorium unitatis christianae, op. cit., p. 131.

${ }^{33}$ Resumo y a continuación cito el pasaje en su integridad: el pueblo que será creado, alabará al Señor. Puesto que crear es sacar algo nuevo de la nada, ¿cómo va a ser posible eso cuando ya había sido creado tanto el pueblo judío como el poderoso e inmenso pueblo gentil? El nuevo pueblo debía surgir de esas dos naciones y no como una nueva propagación carnal de aquellas sino como una creación espiritual. El profeta interpretaba de hecho que el nuevo pueblo tenía que ser creado en espíritu, de forma que anulada toda diferencia carnal, cualquier persona que a él viniera constituyera una emanación espiritual del nuevo Adán, Cristo Nuestro Señor, «Populus qui creabitur, laudabit dominum. Creare siquidem de novo ex nihilo facere est. Quomodo ergo creari populus diceretur Deum laudaturus, cum iam et creati essent tam populus iudeorum quam gentilium potens et numerosissima turba. Neque enim aliquis novus carnalis adam, ex cuius materiali progagine alii homines nascerentur, creandus erat, sed ex iudeis et gentilibus qui iam erant creati, novus populus assumendus. Spiritualem namque creationem propheta intuens, novum populum in novo adam ad creandum in spiritu audiebat, ut, carnis differentia prorsus sublata, omnes quicumque et ex quacumque gente venirent per spiritualem nativitatem ex innocente et inmaculato secundo adam Christo domino nostro spiritualiter emanantes unum populum constituerent.» Ibidem, p. 137.

${ }^{34}$ Los dos intentos de introducir los estatutos de «limpieza de sangre» en Burgos tuvieron lugar en 1550 y en 1584-1585. Ninguno de ellos tuvo éxito. López Martínez, siguiendo los pasos del cronista Alonso de Palencia, afirma que los conversos de Burgos no judaizaban. Eran en cambio hombres de «buena ley» y virtuosos «a cuyo ejemplo la mayor parte de los conversos de España seguía el camino de bien». Es interesante ver que la oposición a los estatutos no vino sólo de ellos. Cfr. «Este cabildo 
Conocemos su labor de fino glosador y traductor de Séneca y Cicerón, así como de hombre de estado y eminente jurista, autor también de escritos políticos que aspiraban a cohesionar la monarquía castellana en torno a su Rey. Queda menos investigada, sin embargo, su producción literaria de carácter espiritual. Al leer su glosa al salmo 43 y un tratado sobre la oración, se descubre a un autor doble, ambiguo, hecho a una escritura alegórica, llena de imágenes épicas y encendidas de una pasión no siempre controlada. La imagen más recurrente en los dos textos de Cartagena que vamos a analizar es la de la guerra. No se trata de la recreación de una lejana memoria bíblica, sino de un presente que invade el texto, de una escritura que se convierte en conciencia vibrante de un drama humano y político.

La Apología super psalmum «Judica me Deus» fue compuesta en latín por su autor y luego traducida por él mismo al castellano. ${ }^{35}$ No sabemos cuándo se escribió, pero el hecho de que se publicara póstumamente -apareció al final del Oracional en la edición murciana de 1487, impresa por Luis Gabriel Ariño y Lope de la Roca- hace pensar en una previa circulación manuscrita.

Esta glosa a un salmo, relacionada con la tradición de la Biblia romanceada, ${ }^{36}$ parece una composición dirigida principalmente a los cristianos nuevos.

dispuso hacer estatutos de la limpieza y calidades que han de tener los beneficiados de esta Santa Iglesia a conforme a el de la de Toledo, lo contradigeron. Un proceso y otros papeles sobre el estatuto de limpieça que hiço esta iglesia». Julio de 1550. Archivo de la Catedral, Burgos, libro 32, ff. 251-286; Nicolás LÓPEZ MARTíNEZ, «El estatuto de limpieza de sangre en la catedral de Burgos», Hispania, 19 (1959), pp. 52-81.

Sobre el gobierno episcopal de Alonso de Cartagena véase L. SerRano, Los conversos Don Pablo de Santa María y Don Alfonso de Cartagena, op. cit., pp. 185-217 y Nicolás LóPez MARTíneZ, «Sínodos burgaleses del siglo XV», Burgense 7 (1966), pp. 211-406.

${ }^{35}$ De la versión traducida por el propio Cartagena se conserva una copia en la Biblioteca del Real Monasterio de El Escorial (Ms. Escorial a-IV-7) junto con la original versión latina (Escorial, Ms, 0-II, 3, ff. 86-90). Cfr. Fernando Díaz Esteban, «Psalms Translations in the spanish tradition: the case of the «converso» Alonso de Cartagena (XV century)», en Rashi 1040-1990, Hommage à Ephraïm E. Urbach. Congrès européen des Études juives, G. Sed-Rajna (ed.), Les Éditions du Cerf, París, 1993, pp. 663-676. P. SAINZ RodRíGUEZ realizó una transcripción parcial del texto del salmo, probablemente basándose en la edición de 1487, conservada en la Biblioteca Nacional de Madrid, Incunable n. 2493, Catálogo 8461. Cfr. Antología de la literatura espiritual española I, Edad Media, FUE, Madrid, Universidad Pontificia de Salamanca, tomo I, pp. 617-630. Para este estudio se ha utilizado el M. 160, conservado en la Biblioteca Menéndez Pelayo de Santander, que es una copia de la edición póstuma. Cfr. Infra nota 37.

${ }^{36}$ Fernando Díaz Esteban, tras analizar la obra de Alonso de Cartagena y cotejarla con los tradicionales comentarios judíos a los salmos, concluye que el obispo de Burgos pertenece a la «free tradition of the Spanish «Biblia Romanceada». In spite of his Jewish stock, as a commentator, he is very far from Jewish commentaries; his commentary is really a spiritual Christian gloss of the Psalm recited by the priest when approaching the altar». Cfr. I., «Psalms Translations in the spanish tradition», op. cit., p. 676.

Hispania Sacra, LXII

125, enero-junio 2010, 43-91, ISSN: 0018-215-X 
El comentario del primer verso del salmo «Juzga me Dios: aparta la mi causa de la gente non santa y del hombre malo y engañoso líbrame», empieza recordando que Dios es el único juez justo, porque, a diferencia de «los humanos regidores», es capaz de escudriñar el corazón de los hombres y de perdonar misericordiosamente los pecados.

Cartagena pide luego a Dios que aleje de sí a «la gente non santa», que según el autor es la encarnación de los siete vicios capitales. Para ilustrarlos recurre a imágenes potentes y sugestivas, casi de infierno dantesco: así, «la gente non santa» se representa como la

«desenfrenada y no domada muchedumbre de mis afeçtiones que como una muy fiera gente continuamente çercan y turban mi coraçón y la traen y empujan como por una manera de fuerça a las cosas que me son dañosas. Ca sy la gente se llama turba porque perturba a los otros, qual ayuntamiento de gentes, más reciamente perturba mi corazón que el tropel y monton de mis pasiones pensamientos y afeçtiones. Ca éste como una esquadra de enemigos entra en los términos de la mi anima».37

Cartagena juega aquí con sorprendente destreza expresiva al identificar, en un primer momento, a la «gente non santa» con su condición humana («desenfrenada y non domada muchedumbre de mis afectiones»), para luego, con un sutil juego de palabras, llamar a la «gente non santa» «turba» porque «perturba» a los otros, y también a su corazón, mucho más que los siete pecados y todas sus afecciones. Esta «gente non santa» es, en definitiva, la «esquadra de enemigos» que asedian su corazón al mismo tiempo que simboliza la maraña de todos los vicios. De ellos se alimenta la belicosa «soberbia guarnida de diversas armas y exhortaçiones» y la «fea esquadra de la envidia».

Como puede observarse, Cartagena utiliza una verdadera y precisa jerga militar: la «gente non santa» o «el enemigo armado»; las armas, el furor ciego; «la batalla de la soberbia»; las escuadras de los enemigos que «cercan» y «derriban». Es la guerra, y su sabio modo de decir y no decir revela el orgullo de quienes, pese a estar expuestos a una terrible tensión, se arriesgaron a permanecer íntegros frente al «enemigo armado»:

«Et en tanto cuadrillas çercan y combaten mi anima, non fallen estos otros que por comoçiones y movimientos corporales pruevan de derribar el muro, cerca de mi conciencia». 38

\footnotetext{
${ }^{37}$ Apología sobre el salmo « Judica me Deus». Contemplaçión mezclada con oraçión conpuesta en latín e tornada en lenguaje castellano sobre el psalmo del profeta David que comiença «Júdgame Dios». M.160, Biblioteca Menéndez y Pelayo de Santander, ff. CXXXVIr-CXLIXr; f. CXXXVIIIr.

${ }^{38}$ Ibidem, f. CXXXIXr.
} 
De hecho, poco después Cartagena invoca la protección divina en contra de «los ingenios» (los artefactos) que la «gente non santa» construye para destruir los muros, en este caso reales, de los conversos.

En esta lectura del primer verso del salmo 43 emerge entre líneas la imagen de una comunidad, de un pueblo a la defensiva, asediado, cercado por un enemigo en armas: la sociedad cristiano vieja, representada con la alegoría de una legión de envidiosos y de gente codiciosa («la gente non santa»).

El obispo de Burgos penetraba en el imaginario del judeo-converso, rediseñaba el alma judía escogiendo uno de los lugares más representativos de esa tradición, el monte de Sión, el lugar de la morada de Dios según David. A este contrapone otro «monte santo», otra morada, otra «subida» que hay que emprender para disponerse al encuentro con Dios: la Eucaristía. ${ }^{39}$ Este sacramento señala el momento culminante de la glosa al salmo 43. El autor había recorrido todos los lugares de la memoria judeo-conversa -el monte santo, el arpa, la tristeza, la soledad del pueblo de Israel- hasta desembocar finalmente en el manjar divino de la Eucaristía. No hay dos tradiciones que se fusionan, como podría parecer, sino una única historia de la salvación en la que el «hombre interior», «alumbrado por la fe», 40 puede finalmente saborear los «efectos de gracia» que rebosan de este «santo sacramento». ${ }^{41}$

${ }^{39}$ Ibidem, f. CXLIIv: «Sy alguna vez fuy y me allegué a la firmeza de tu amparo, la luz tuya y la verdat tuya lo fisieron. Ca ellas me retrayeron al monte santo tuyo, a las moradas tuyas. Et qual otro monte santo tuyo ay si non la altura de tu santa fee. Ca este es el monte santo tuyo en que nasçe la fructuosa gordura de los santos sacramentos. Onde dize el profeta...».

${ }^{40}$ Esta concepción de la fe como gracia, efecto de un «alumbramiento» divino tan propio de la espiritualidad de los conversos, está muy presente en la glosa de este salmo de Alonso de Cartagena. A este propósito, me limito aquí a seleccionar unos de los pasajes más significativos: «Pero yo que soy el escuresçido de tiniebras y pecados non veo carrera por donde venga a rrecorrir a ty. Yo abaxado de los errores de mis maldades no puedo alcançar la doctrina de la verdad. Salvo si tu que eres $l u z$ verdadera me alumbrares (...) Por ende Señor enbía la luz, tuya y la verdat tuya. (...).Tu que eres luz y verdad ven en mí porque el resplendor tuyo alumbre los ojos de mi entendimiento para que vean las cosas espirituales (...). Ca no puede andar sin entropeçar el que no tiene luz ni fuyr de error el que non es regido por la verdat (...). Por ende con toda humildat llamaré a ty para que enbies la luz tuya y verdad tuya delante mí, que alumbre mi entendimiento y guie las mis pisadas, así alumbrado y guíado con grande confiança llamaré al Señor. Et entraré al altar de Dios mio, me allegaré a Él a resçebir la santa comunion» (la cursiva es mía). Apología sobre el salmo «Judica me Deus», op. cit., f. CXLIIr- v y CXLIVr. Para las relaciones entre espiritualidad conversa y paulinismo, véase de M. L. GioRDANo, Apologetas de la fe. Elites conversas entre Inquisición y Patronazgo en España, FUE, Madrid, 2004.

41 «Por ende, esta es verdadera vianda y verdadera ventaja que sostiene la substançia incorporal de nuestra anima (...) y delecta de una devota alegría al nuestro omne interior que es nuestro espíritu. Et lo que más es no solamente Señor das estos effectos de graçia en este viaje temporal deste mundo a los que derechamente lo toman (...). Ca tu eres el que dizes fablando de este santo sacramento: «Sy alguno comiere deste pan bivirá para siempre»» (la cursiva es mía), Apología sobre el salmo "Judica me Deus», op. cit., f. CXLVv.

Hispania Sacra, LXII

125, enero-junio 2010, 43-91, ISSN: 0018-215-X 
«E AUN ENTRE LOS BASTARDOS, MUCHOS OVO E AY INSIGNES Y GLORIOSAS PERSONAS»

Alonso de Cartagena escribió el Oracional a petición de Fernán Pérez de Guzmán, alrededor de 1454, como se deduce por la mención del autor a la reciente muerte de Juan II..$^{42}$ Insertada en el género literario didáctico-moral -se trataba de enseñar a rezar- esta obra sorprende por ser una temprana expresión de la espiritualidad de la devotio moderna: la oración no es el «menear de los labios nin al dar de las bozes», sino «la elevaçión del coraçón en Dios».43 Entre todas las prácticas cristianas, sólo este tipo de oración es un «acto interior» de fe, ya que acredita una experiencia auténtica y una devoción sincera. Aquí Cartagena propone, en el envoltorio del tratado ascético-moral, una idea original y al mismo tiempo muy polémica: construir un árbol genealógico de la oración, en el que exalta sus nobles orígenes y alto linaje. Tras esta presentación, el obispo de Burgos se sumerge de lleno en el desafío: demostrar que el linaje de la oración -alegoría de la religión interior practicada por los conversos- es más alto y puro que el de las «obras exteriores». Estas últimas simbolizan, de forma intencionadamente esquemática, todo el mundo espiritual cristiano viejo. «Las obras exteriores», «aunque buenas y virtuosas», por el hecho de estar en contacto con los apetitos inferiores, son «bastardas». Es la oración, en cambio, la que merece el título de progenitora legítima, puesto que es la «más excelente» en linaje por descender directamente, sin mezcla ninguna de corporalidad, de las altas virtudes.

Y anticipándose a una acusación, se protege diciendo: «E non cuyde alguno que por poner este enxienplo de concubina, atribuymos macula alguna a la limosna, ayuno, castidad»; estas «obras exteriores» le parecen, de hecho, todas y cada una de ellas muy elogiables. Y concluye sin inhibiciones, descubriendo el juego alegórico por un breve instante: «E aun entre los bastardos, muchos ovo e ay insignes y gloriosas personas». ${ }^{44}$

«Bastardos», «macula», «linaje», «hermanos», «fijo de un padre»: no faltan los indicios, terminológicos y semánticos, concentrados en el escaso espacio de poco más de una página, para identificar con claridad un discurso paralelo, construido sobre el hilo de la ambigüedad, alusivo y afilado como una espada. Cartagena transforma a los acusados en acusadores haciendo, como él mismo advierte, un «exenplo grosero» para dejarlo claro a sus lectores. Él sabe que

\footnotetext{
42 Del «Oracional» se conocen varios manuscritos y una edición murciana de 1487, la misma en la que apareció la Apología sobre el psalmo Judica me Deus. Para este estudio se utiliza la transcripción realizada por S. GoNZÁLEZ QUEVEDO Alonso, El «Oracional» de Alonso de Cartagena: edición crítica (comparación del manuscrito 160 de Santander y el incunable de Murcia), Albatros Hispanófila, Valencia, 1983.

${ }^{43}$ Ibidem, p. 148.

${ }^{44}$ Ibidem, pp. 154-155.
} 
quien lea se sentirá identificado con ese estilo espiritual al que ofrece todo género de alabanzas, el de los actos interiores. Entonces, si hablamos de «linaje», Alonso de Cartagena parece indicar, no sin cierta audacia, que «los bastardos» no eran ellos.

En el Oracional encontramos el perfil espiritual de los conversos del siglo XV. En el intento de re-definir su identidad -ellos «son» la religión de la gracia, los cristianos viejos «son» la religión de los actos exteriores-, el obispo de Burgos reivindicaba para su gente el orgullo de descender del «linaje excelente de la oración».

Es evidente la ironía con la que juega con el término «linaje», vocablo utilizado para dar la vuelta a la supuesta inferioridad del judeo-converso, proclamada por García de Mora en su Memorial y transformada ahora en superioridad.

Cartagena continúa desgranando consejos, como lo haría un abogado con su cliente, prudentemente resguardado por el tono filosófico-moral del tratado. A propósito de la virtud de la verdad, distingue entre el simular y el disimular: ${ }^{45} \mathrm{el}$ primero es un acto falso y por lo tanto despreciable, mientras que el segundo, que consiste en el «non demonstrar nin decir lo que fizo», no constituye una mala acción, porque no está orientado a procurar ningún daño.

Era una clara invitación a la prudencia, a la reserva, como había enseñado San Agustín: «E pluguiesse a Dios que mis frayres fuessen ypócritas». No era cuestión de mentir, sino tan sólo de no hablar públicamente de sus propios «errores». «Non te digo que te publiques mas que te confieses», amonestaba el obispo de Burgos, convencido de que el foro de la confesión era el único habilitado para recibir los secretos del alma, el único autorizado para perdonar y, en definitiva, el único tribunal de la conciencia legitimado por Dios y por la Iglesia para desempeñar esa función.

Aunque el Santo Oficio todavía no se había instalado, después de los hechos de 1449 una afirmación así ya tendría plena vigencia como punzada en contra de la mentalidad inquisitorial manifestada en esos sucesos.

Otro punto importante del Oracional es la oración del Pater Noster. Le dedica tres capítulos, ${ }^{46}$ en los que pasa por el cedazo cada palabra y desmenuza el significado de cada expresión. Me ha parecido particularmente significativa la inteligencia con la que el autor aprovecha la oportunidad que el texto le brinda para adaptarlo al perfil espiritual de sus lectores.

A ellos se dirige cuando, comentando el inicio de la oración, afirma: ««Padre nuestro» non mío solamente, mas de todas las criaturas e este es el mas au-

45 Ibidem, pp. 100-101.

${ }^{46}$ Ibidem, pp. 125-135. 
torizable e el mas dulçe nonbre quanto a nos que se pueda aver». Un siglo más tarde Teresa de Ávila volvió con una glosa sobre el Padre Nuestro, intentando una operación parecida a la del obispo de Burgos. Insistía en el sustantivo «padre»y en el adjetivo «nuestro» para subrayar la unidad de los cristianos, hijos de un origen común. ${ }^{47}$

El prelado burgalés era consciente de que el atributo «padre» representaba un problema, porque degradaba y humanizaba excesivamente la potencia de Dios. ${ }^{48}$ Por eso se preocupó de aclarar este punto:

«La palabra «padre» señorío muestra. E asy diciendo «Padre nuestro», dezimos Señor nuestro y Padre. E asy en Le decir «padre» Le damos dos superioridades: señorío e paternidad». 49

Las palabras con las que cierra su Oracional contienen el núcleo de esa religión interior -el iluminismo paulino- que se afirmó en España en el siglo siguiente. Es interesante observar cómo Cartagena sitúa su visión de la fe como alumbramiento divino en el escenario mental completamente judaico de la eterna lucha entre las tinieblas y la luz. En uno de los puntos más líricos de la obra describe la fe como un rayo de luz que ilumina la breve noche de verano que es la vida del hombre:

«E paresçe a mi, aunque mis pecados e culpas non me lo bien dexan gustar que acaesçe a las vezes en la oración a los ojos del entendimiento lo que en algunas noches veemos acaesçer a los ojos del cuerpo. Ca bien vistes si sse vos mienbra e non dubdamos que se vos menbrará en algunas de las breves noches del ardiente verano que propiamente fablando estío sse llama, grandes turbones e truenos en uno con ellos e de espaçio en espaçio algunos luzientes relánpagos que entran a las vezes por la finiestra el fulgurante relánpago que torna la camara clara de claridat muy graçiosa e quando los ojos quieren entender e mirar en ella pártesse tan de rebato commo de rebato entró. E queda la camara escura commo estaba de primero. E sy queredes esto proporçionar con interna especulaçión o retornarlo a los ojos del entedimiento, ¿qué mas breve noche puede ser que el espaçio de nuestra vida tenporal e non sin razon se puede llamar noche pues es tenebrosa e obscura? (...) Pero segund creo que mirastes quando con algund tanto con actenta devoçión en algund logar apartado suspirastes a Dios pidiendo remedio en vuestras angustias que sentiriades una manera de claridad en vuestro entedimiento e anchura en el coraçon que viene a desora e consuela algund poco e de arrebato sse parte e tórnase omne en el primero turbon (...) Nuestro Señor viene en el omne quando con devota oraçión a El sse recorre que viene con la claridat de su consolaçión commo una luz fulgurante a de-

47 Santa Teresa DE Jesús, El camino de perfección, Obras Completas, E. de la Madre de Dios y O. STEGGINK (eds.), BAC, Madrid, 1976, pp. 287 y ss.

${ }^{48}$ En la tradición judaica no era frecuente dirigirse a Dios en los términos de padre. Sólo el profeta Isaías interrumpió claramente esta tradición. Esta sería la razón por la que se le llama «el evangelista».

${ }^{49}$ El «Oracional» de Alonso de Cartagena, op. cit., p. 126. 
sora e pártesse a las vezes a desora e ayna. Pero tanto más dura quanto más el orante la finiestra de su coraçón tiene abierta»..$^{0}$

Nada de lo dicho hasta ahora sorprende, puesto que el siglo XV para los conversos no fue más que una sucesión de guerras civiles, revueltas y persecuciones, cuya sombra no pudo sino reflejarse en la literatura doctrinal.

En cambio, un nuevo dato sobre el que reflexionar late en la finalidad de la clave alegórica de los tratados aquí analizados: la construcción de una imagen alternativa al espejo deformante que ofrecía la sociedad de su tiempo..$^{51}$

A los muros defensivos, físicos y vulnerables, se intentó oponer otro «muro», el de una «conciencia» inexpugnable. Mediante una labor tenaz y constante dentro de la memoria Cartagena fijaba los pilares de esta nueva identidad. El más eficaz y duradero de ellos fue la identificación de los conversos con la religión interior de la gracia, desde la cual pudieron pensarse como cristianos, aunque con unos rasgos distintos de los demás. Ellos hubieran sido cristianos, pero de otra manera. Esta «otra manera» fue el paulinismo, «el sentimiento interior de la gracia», la espiritualidad interior, que correspondía, aunque no del todo, a lo que en Europa se llamó la devotio moderna. El lenguaje alegórico y la ironía punzante de sus escritos se convirtieron en el vientre cálido que acogió la gestación de esa nueva conciencia cristiana.

\section{LA «CIUDAD DE NUESTRA CONCIENCIA»: LA BATALLA DE TERESA DE CARTAGENA}

Después de la muerte de Alonso de Cartagena en 1456 pareció haber pasado el momento para desarrollar alguna estrategia de integración, tal y como había sugerido el obispo de Burgos. ${ }^{22}$ De hecho se registró un preocupante incremen-

50 Ibidem, pp. 203-205.

51 Juan HERnÁNDEZ FRANCO ha puesto énfasis en el uso del concepto de «limpieza de sangre» en los mecanismos de formación de la identidad conversa desde la vertiente de los cristianos viejos, es decir desde la óptica opuesta, pero justamente por eso complementaria, a la que se analiza en este estudio. Véase al respecto su artículo «El pecado de los padres: construcción de la identidad conversa en Castilla a partir de los discursos sobre limpieza de sangre», Hispania, LXIV/2, n. 217 (2004), pp. 515-542.

52 Como ha observado oportunamente Haim BeinarT, ni Fernán Díaz de Toledo, ni Juan de Torquemada, habían previsto en sus escritos un «plan de asimilación». El único en hacerlo parece haber sido Alonso de Cartagena, quien vio en la falta de asimilación de los conversos la raíz del problema, puesto que quien había dejado su nación necesitaba algo tan elemental como una buena acogida en la nueva. Según el obispo de Burgos -sigue Beinart- «Conversos should hold offices and receive titles even equivalent to those they had before their conversion. He postulates three kinds of existing nobility: religious, natural or moral, civil. These three kinds were to be found among the Jews when they were in their land and enjoyed statehood. (...) Only through kindness, understanding, and absorption according to their status into Christian Society, and by letting them enjoy all the privileges which come

Hispania Sacra, LXII

125, enero-junio 2010, 43-91, ISSN: 0018-215-X 
to de la conflictividad social. La primera mitad del siglo XV había sido, desde el punto de vista de las revueltas anti-conversas, un periodo bastante pacífico comparado con los años posteriores a 1449. Desde entonces se desencadenó una secuencia de ataques, uno tras otro: 1459-1464, revueltas en Burgos; 14621463, insurrección en Sevilla contra las tasas y los oficiales del rey; 1464, desórdenes en Valladolid; 1465, conflictos en Toledo y Sevilla; 1467, motines en Toledo y Burgos; 53 1468, matanza de judíos en Sepúlveda; 1470, nuevos alborotos en Valladolid; 1471, explosión de otra revuelta en Burgos; 1473, masacres de conversos en Córdoba, Montoro, Bujalance, Adamar, La Rambla, Santaella, Écija, Andújar, Úbeda, Baeza, Almodóvar del Campo, Jaén; 1474, ataques a los conversos de Segovia y Valladolid; 1476, siguen los motines en Segovia; 1478, Toledo fue otra vez bajo la amenaza de un nuevo ataque anti-converso. ${ }^{54}$

to those who belong to Christian society will the Jewish Converso problem find its solution, to the benefit of the Conversos as well as Christianity and Spain». Cfr. I., «The converso community in 15th century Spain», R. D. BARNETT (ed.) The Sephardi Heritage. Essays on the history and cultural contribution of the Jews of Spain and Portugal. Ktav Publishing House Inc., New York, 1971, vol. I., pp. 425478, pp. 433-434. Cfr. Alonso DE CARTAGEnA, Defensorium unitatis christianae, op. cit., pp. 153-154 y p. 215 y ss.

53 Un domingo de julio de 1467, desde el púlpito de la Catedral de Toledo, se proclamó un decreto de entredicho contra la ciudad de Maqueda, por una intromisión de su alcalde mayor extraordinario, Álvar Gómez de Ciudad Real, en la recaudación de unas rentas capitulares. Antiguo secretario de Enrique IV, Alvar Gómez estaba presente en el momento de la lectura de la proclama e intentó arreglar el asunto, llegando a un acuerdo con el beneficiado del cabildo. Pero la irrupción de Fernando de la Torre, un converso muy conocido en la ciudad, cambió el rumbo de la situación: Alvar Gómez, animado por De la Torre, junto con un grupo armado de conversos, entró en la Catedral y mató a dos clérigos. La reacción de los cristianos viejos no se hizo esperar: éstos se armaron y, después de las bajas de los primeros combates, consiguieron triunfar contra los atacantes. De los tres principales capitanes del bando converso, dos de ellos acabaron ahorcados en las plazas: el mencionado De la Torre y el licenciado Alonso Franco, miembro de una familia emparentada con los Cartagena. El primero había sido nombrado secretamente por los conversos como su capitán; éste, con el dinero de todos, compraba las armas y las depositaba en su casa, que se convirtió en un auténtico arsenal de notables dimensiones, pensado para que se pudiera acudir a él en los «rebatos y casos repentinos, y cuando pensasen poder desbaratar a cualquier turba de cristianos viejos y apoderarse de los vencidos». En cuanto al tercero, el conde de Cifuentes don Alonso de Silva, protector de los conversos, tuvo que huir y pedir refugio en el monasterio extramuros de San Bernardo. Los otros conversos se retiraron -muchos fueron hospedados y protegidos por los monjes de los monasterios cercanos- y desde entonces empezó el saqueo de sus casas y de sus bienes.

En junio de 1468, cuando Toledo acababa de volver a la obediencia real, después de protagonizar este otro episodio de rebelión, Enrique IV ratificó la prohibición para los conversos de acceder a puestos públicos, quedando así vigente el contenido de la Sentencia-Estatuto de Pedro Sarmiento. Cfr. E. Benito Ruano, Toledo en siglo XV, CSIC, Escuela de Estudios Medievales, Madrid, 1961, pp. 93-108.

${ }^{54}$ Angus MACKAY, «Popular movements and pogroms in fifteenth century Castile», Past and Present, n. 55, (May 1972), pp. 33-67. Este artículo sugiere una interesante relación entre los pogroms anti conversos del siglo XV y el deterioro de la coyuntura económica. Sobre las revueltas del siglo XV véase, además, J. AMADOR DE LOS Ríos, Historia social, política y religiosa de los judíos de España y Portugal, Aguilar Ed., Madrid, 1960, pp. 635-641, 643, 662-663. 
Todas estas rebeliones armadas fueron un espasmo de rechazo con el que la sociedad cristiano vieja reaccionaba ante la exitosa integración de los conversos, es decir, ante un movimiento que había avanzado sin parar desde el gran pogrom de 1391 hasta la primera mitad del siglo XV. Las masacres se tradujeron en un escenario mental que encontró en la literatura espiritual un recurso con el que animar, reconfortar, curar e incluso descansar, tal y como necesita quien vuelve del campo de batalla.

Hacia los años setenta del siglo XV, otra generación de escritores conversos,, 55 entre los que se hallan Teresa de Cartagena y Hernando del Pulgar, recogió la herencia intelectual de Fernán Díaz de Toledo, Juan de Torquemada, Lope de Barrientos y Alonso de Cartagena: en otras palabras, todos los que habían reaccionado a los hechos de 1449 empleando el arma del tratado doctrinal. En el caso del cronista real, su mirada sobre la realidad fue la de «los fundadores de la intelectualidad castellana» la familia Ha-Levi y su círculo. ${ }^{56}$ No sorprende, entonces, que en sus escritos vuelvan a aparecer algunas ideas del obispo de Burgos. Como es sabido, sus llamamientos a la caridad paulina y su crítica a los métodos inquisitoriales cayeron en saco roto. ${ }^{57}$

Precisamente en los años cruciales anteriores a la instalación del tribunal de la Inquisición, Teresa de Cartagena, hija de un hermano de Alonso, don Pedro, ${ }^{58}$ y por lo tanto nieta de don Pablo de Santa María, escribió su primer tratado, Arboleda de los enfermos, ${ }^{59}$ al cual siguió otro escrito, Admiraçión operum Dey. ${ }^{60}$

\footnotetext{
55 Tal vez Teresa de Cartagena podría incluirse en esa generación de los «bellicose converso prophets of the 15 century» a la que se refiere Stephen GILMAN, «A generation of Conversos», Romance Philology, vol. XXXIII, n. 1, (August 1979), pp. 87-101.

56 Sobre la «continuidad intelectual» entre Alonso de Cartagena y Pulgar remito a las bellas páginas de J. L. Villacaña Berlanga, La monarquía Hispánica (1284-1516), Espasa Calpe, Madrid, 2008, pp. 593-602.

57 Particularmente interesante es una carta que Hernando del Pulgar dirigió en 1481 a don Pedro González de Mendoza, en la que estrenaba una «sensata teoría de represión pública», fundamentada en San Pablo y San Agustín. Cfr. Francisco Cantera Burgos, «Fernando del Pulgar y los conversos», Sefarad, 1(1944), pp. 295-348. Pulgar siguió defendiendo a los conversos en la Crónica de los Reyes Católicos precisamente en estos dramáticos años que prepararon la puesta en marcha del Santo Oficio. Cfr. J. Mata Carriazo (ed.), Fernando del Pulgar, Crónica de los reyes católicos, Espasa Calpe, Madrid, 1943.

58 Cfr. supra nota 26.

${ }^{59}$ Como la glosa al salmo Judica me Deus de su tío, Alonso de Cartagena, la Arboleda de los enfermos debió de circular en forma manuscrita, puesto que no he encontrado ningún ejemplar incunable del tratado en los repertorios bibliográficos. De esta obra se conoce sólo una copia, conservada en la Biblioteca del Real Monasterio del El Escorial (manuscrito h-III-24) y transcrita por un copista de principios del siglo XVI. La primera edición moderna de los escritos de Teresa de Cartagena se debe a L. J. Hutton, Arboleda de los enfermos y Admiraçión operum Dey, Anejos del Boletín de la Real Academia Española, Anejo XVI, Madrid, 1967.

${ }^{60}$ Acusada de plagio, Teresa se defendió escribiendo esta secunda obra en la que, para hacer valer su derecho de mujer escritora, utilizó una argumentación muy franciscana: Dios puede realizar maravi-
} 
Ambas obras fueron dirigidas a su protectora Juana de Mendoza, ${ }^{61}$ mujer del poeta Gómez Manrique, corregidor de Toledo a partir de 1477. Teresa debió de nacer entre 1420 y 1435.62 Se crió con su familia en la calle Cantarranas la Menor, en Burgos. ${ }^{63} \mathrm{Su}$ casa fue centro de acogida de miembros de la realeza y de la nobleza de visita por España y huéspedes de los monarcas castellanos Juan II (1406-1454) y Enrique IV (1454-1474). Además, sirvió de fortín a don Álvaro

llas a través de sus criaturas, sean varones o mujeres. Cfr. a este propósito, la atenta reconstrucción de Ronald E. SuRTZ, Writing Women in Late Medieval and Early Modern Spain. The Mothers of Saint Teresa of Avila, University of Pennsylvania Press, Philadelphia, 1995, pp. 21-40.

${ }^{61}$ Aunque en el caso de la Arboleda su autora no mencione directamente a Juana de Mendoza, es bastante probable que la «señora» a la que se refiere en las primeras líneas de la obra sea la misma persona a quien dedicó su segundo escrito. Interesantes informaciones sobre la mujer de Gómez Manrique aporta el estudio de Ronald E. SURTZ, «In search of Juana de Mendoza», Power and Gender in Renaissance Spain. Eight Women of the Mendoza Family, 1450-1650, en H. NADER (ed.), University of Illinois Press, Urbana and Chicago, pp. 48- 70. Cfr., también, Alan DeYERMOND, «Women and Gómez Manrique», en «Cancionero Studies» in Honour of Ian Macpherson, A. DEYERMOND (ed.), Department of Hispanic Studies, Queen Mary and Westfield College, London, 1998, pp. 69-87.

${ }^{62}$ Esta era la propuesta de F. CANTERA BuRgos, Alvar García de Santa María, op. cit., p. 538.

${ }^{63}$ Sobre su familia, sabemos que su padre, Pedro de Cartagena (1387-1478), se casó en primeras nupcias con María Sarabia, de ascendencia noble. De la unión nacieron cinco hijos: Alonso de Cartagena, Álvaro de Cartagena, Juana, Teresa y María Sarabia. El primogénito siguió la profesión del padre, guarda del cuerpo del rey y hombre de armas. Se casó con doña María Hurtado de Mendoza; tuvo tres hijos y murió joven, en 1467, en medio de un alboroto que iba a apaciguar en Sasamón. Álvaro de Cartagena, otro hermano de Teresa, fue un personaje muy cercano al soberano puesto que según los documentos «tuvo asiento en la casa del Rey». Fue él a quien el monarca mandó para escoltar la persona del condestable cuando éste fue perseguido por los burgaleses; participó en la restitución de la fortaleza de Lara a Juan II y a la ciudad de Burgos. Como el hermano mayor, este caballero murió en batalla, en 1471, mientras servía a su rey. Fue sepultado en la capilla mayor del convento de San Pablo.

Juana de Cartagena -«Leonor»o «María de Cartagena» en algunos documentos- estuvo casada con Diego Hurtado de Mendoza, hijo del Prestamero a quien don Pedro, su padre, mató en duelo. Dona Juana fue mujer culta y entregada a la lectura. Su tío Alvar relata haberle prestado un libro de Boecio y que ella no le devolvió nunca. Fue la madre del poeta Iñigo de Mendoza e inspiradora de una de las obras de éste, Vida Christi. De María Sarabia, otra hermana de Teresa, no se tienen noticias, excepto una breve mención en el testamento de su tío, el obispo Alonso de Cartagena.

El padre de Teresa de Cartagena se volvió a casar más tarde con la noble Mencía de Rojas, que le dio dos hijos: Lope de Rojas o de Cartagena (1444-1477) y Elvira de Rojas o de Cartagena.

Otros hermanos de Teresa fueron los tres hijos naturales de don Pedro: Pablo de Cartagena, Gonzalo Pérez de Cartagena y Pedro de Cartagena. De este último, conocido como «el Romo», se sabe que vivió en la corte de los Reyes Católicos, de quienes recibió un solar en Burgos por los muchos servicios prestados; como otros hermanos suyos, encontró la muerte en la guerra.

La vida del otro hermano, Gonzalo Pérez de Cartagena, está más documentada gracias a que desempeñó varios cargos al servicio del rey Católico y de la reina Juana su hija; fue alcaide de la fortaleza de Bienquerencia, de la villa y fortaleza de Ágreda y de la de Lara; participó en varias campañas en contra de los moros. Murió en 1519 y recibió sepultura en la capilla de Nuestra Señora de la Piedad de San Agustín de Burgos, fundada por él.

Cfr. F. CANTERA Burgos, Alvar García de Santa María, op. cit., pp. 497-519. 
de Luna cuando, después de su arresto, se refugió allí para no caer en manos de los burgaleses.

Es de suponer que Teresa, al igual que sus hermanos, recibiera una buena formación, puesto que contaba con recursos notables a su alcance, como las bibliotecas de los Mendoza, con quienes tuvo lazos de parentesco y de amistad. ${ }^{64}$ Teresa debió de ser instruida por un preceptor, como era frecuente en las familias acomodadas, antes de dejar Burgos para ir a Salamanca, ${ }^{65}$ donde frecuentó la universidad.

La revuelta toledana de 1449 marcó un giro en su vida. Como consecuencia de ella vivió en su propia piel la animadversión de los cristianos viejos hacia los descendientes de linaje judío. No es casual que en la primavera de aquel año ya se preparaba a dejar el convento de Clarisas, al que se había retirado como religiosa, para marcharse a otro donde se sintiera mejor acogida. ${ }^{66}$

${ }^{64}$ Don Pedro de Cartagena, padre de Teresa, después de haber matado en duelo a Juan Hurtado de Mendoza, prestamero mayor de Vizcaya, para poner paz entre ambas familias, casó a dos de sus hijos, doña Leonor y Alonso de Cartagena, respectivamente con Diego Hurtado y María, hijos del prestamero a quien había quitado la vida. Ibidem, pp. 470-471.

65 «Los pocos años que yo estudié en el estudio de Salamanca». Cfr. L. J. HutTon (ed.), Arboleda de los enfermos, op. cit., p. 103.

${ }^{66}$ Debemos estas noticias a los recientes hallazgos de Dayle Seidenspinner. Gracias a ellos se ha podido aclarar cuál fue el convento donde se retiró Teresa y también que éste no fue el único. Para probarlo existen dos documentos rescatados por la estudiosa, publicados por V. BELTRÁn DE HEREDIA en el Bulario de la Universidad de Salamanca (1219-1549), 3 vols. Universidad de Salamanca, 1966-1967. En el primero, con fecha 3 de abril de 1449, (Reg. Suppl. 436, fols.114v-115, Archivo Vaticano) Alonso de Cartagena, obispo de Burgos, pedía al papa una dispensa para que su sobrina pudiera ser trasladada desde el monasterio burgalés de Santa Clara extramuros «ad ordinem sancti Benedicti et Cisterciensem»; en el segundo, fechado casi un mes después, el 2 de mayo (Reg. Suppl. 436, fol. 145, Archivo Vaticano), el prelado pedía que su sobrina, al alcanzar la edad de veinticinco años, pudiera ser elegida para algún cargo en el nuevo monasterio.En el primer documento se mencionan fugazmente las razones que explican el cambio, alegando que, para la tranquilidad de su espíritu, habría motivos suficientes por los que no resultaba adecuado continuar en dicho monasterio y en dicha orden religiosa, «(...) Cum animi sui quiete commode nequeat deinceps in hujusmodi monasterio et ordine ex certis rationalibus causis remanere». Según Seidenspinner, las «ciertas causas razonables», a las que alude Alonso de Cartagena en su petición, harían referencia al ambiente enrarecido e intranquilo que se vivía en los monasterios de aquella orden precisamente en un momento de gran tensión, debido al reciente estallido de la revuelta toledana y a la introducción de los primeros estatutos de limpieza de sangre contra los conversos. En la carta, se añadía de hecho una referencia al trato amable que Teresa no habría recibido en el monasterio franciscano y esperaría recibir en el nuevo, «in quo regularis vigeat observantia et benivolas invenerit receptrices» («en el que floreciera la observancia y encontrara una benévola acogida»).

En relación con el segundo documento, el obispo de Burgos quería asegurarse que el cambio de orden no perjudicara la posición de su sobrina en el nuevo monasterio, por lo que sugería su promoción a un cargo de responsabilidad una vez alcanzados los veinticinco años. Esta segunda carta resulta muy útil para definir la fecha de nacimiento de Teresa de Cartagena: si en 1449 ella no había cumplido todavía los veinticinco, debió de nacer después de 1424.

Hispania Sacra, LXII

125, enero-junio 2010, 43-91, ISSN: 0018-215-X 
Respecto a la datación de su obra, las opiniones divergen: Américo Castro la sitúa hacia $1470,{ }^{67}$ mientras que Cantera Burgos la ubica entre 1453 y 1460,68 secundado por Hutton y Deyermond. ${ }^{69}$ Aunque resulta todavía problemático poner una fecha al tratado de Teresa, creo que el momento de renovada tensión entre cristianos viejos y conversos, visible en el clima revuelto de los años sesenta y setenta, puede sugerir un marco para ubicar la redacción de la Arboleda. En esos años el poder de las oligarquías conversas no había sido derrotado del todo, aunque estuviera muy debilitado. Fue «necesaria», pues, la Inquisición, una institución «popular» instaurada por una reina «popular», para poder liquidar los residuos del poder de esa aristocracia urbana. ${ }^{70}$

A pesar de estos hallazgos, hay un punto que todavía permanece oscuro en la biografía de Teresa de Cartagena: falta aclarar cuál fue el monasterio que la acogió después de haber dejado el franciscano. Seidenspinner-Núñez se inclina por el de las Huelgas de Burgos pero no aporta fuentes documentales para comprobarlo. Cfr. Dayle SEIDENSPINNER-NuÑEZ, Yonsoo KIM, «Historicizing Teresa: reflections on new documents regarding Sor Teresa de Cartagena», La Corónica, 32.2 (Spring, 2004), pp. 121-150.

En mis investigaciones en Burgos no he encontrado pruebas en la documentación del archivo de Las Huelgas que pueden confirmar la hipótesis sugerida por Seidenspinner. Desafortunadamente no he podido entrar en el archivo del monasterio cisterciense de Villamayor de los Montes, situado a unos $40 \mathrm{Km}$. de Burgos, porque se halla en fase de reorganización. No descartaría que el monasterio que pudo acoger a Teresa, después de dejar a las clarisas, fuera el de San Ildefonso, de religiosas agustinas. La comunidad de dicho convento, al que su tío Alonso otorgó escritura de fundación en el mismo año de su muerte, en 1456, agradecida por las cuantiosas donaciones que aportaron el obispo y, después de él, su sobrino don Sancho de Prestines, arcediano de Lara y nuevo patrón de San Ildefonso, acogió a once parientas suyas sin dote. Es posible que Teresa fuera una de ella. En el testamento de Sancho Prestines encontramos esta interesante afirmación, aunque por la fecha tardía del documento difícilmente podría referirse a Teresa de Cartagena: «Item mando que den mis erederos a Juan de la Concha mi criado tresmil e veinte cargas de trigo para una persona parienta que el sabe que entrò en una religión e se a de passar a otra (...); encargo la conciencia el dicho Juan de la Concha que assi lo haga cumplir e lo cumpla como enttremi y esta dicho e mando que quando se passare de aquella religion a otra la dicha mi parienta». Archivo de la Catedral de Burgos, Testamento de Sancho de Prestines, Libro 112, ff. 51-68, Año 1497 (fol. 63 v).

Según el registro catastral del Archivo de la Diputación Provincial de Burgos, el convento de San Ildefonso aparece censado en el catastro de Ensenada de 1751 (contaba con 33 monjas, 2 casas, 3 censos, 49 juros y la tercera parte de los diezmos parroquiales). Otra información proviene de una carta de la abadesa del monasterio agustino burgalés de Santa Dorotea, enviada al arzobispo de Burgos con fecha febrero 1876. En la epístola se comunicaba que había fallecido una religiosa lega procedente del extinguido convento de San Ildefonso, que resulta agregado al de Santa Dorotea desde 1 de junio de 1858. De hecho, en una carta anterior, del año 1857, se decía que la llave del archivo del monasterio de San Ildefonso la tenía la madre abadesa de Santa Dorotea (Archivo Diocesano de Burgos, «Religiosas Agustinas de Santa Dorotea», Burgos, 1480-1960, sign. 5-2-14). Se puede concluir entonces que una vez desamortizado el convento fundado por el obispo de Burgos -y eso no pudo ser más tarde de 1858- las monjas restantes y el archivo del mismo se trasladaron al de Santa Dorotea. Desafortunadamente no he podido comprobar esta hipótesis, porque de momento no es posible acceder al archivo de este convento.

67 A. CASTRO, España en su historia, op. cit., p. 309, n. 56.

${ }^{68}$ Cfr. F. Cantera Burgos, Alvar García de Santa María, op. cit., p. 546.

${ }^{69} \mathrm{Cfr}$. Alan DEYERMOND, ««El convento de dolençias»: the works of Teresa de Cartagena», Journal of Hispanic Philology, Vol. 1, (1976), pp. 20-29.

70 Angus MaCKAY, «Popular movements and pogroms in Fifteenth-Century Castile», op. cit., p. 64. 
Esta bulliciosa realidad y el desasosiego al que llevó son el telón de fondo del tratado de Teresa. Por esta razón los intentos de incluirlo en el marco del género consolatorio, ${ }^{71}$ que alcanzó su máxima difusión en España en la década 1450-1460, no ayudan a entender su verdadero mensaje ni su finalidad, aunque formalmente se establecen relaciones muy claras con ese género literario..$^{72}$

La imagen de una segregación infamante está presente desde el comienzo de la Arboleda.

«Grand tiempo ha virtuosa señora, que la niebla de tristeza tenporal e humana cubrió los términos de mi beuir e con un espeso toruellino de angustiosas pasyiones me lleuó a una ýnsula que se llama «Oprobrium hominum et abiecio plebis» donde tantos años ha que en ella biuo, si vida llamar se puede, jamás pude yo ver persona que endereçase mis pies por la carrera de paz, nin me mostrase camino por donde pudiese llegar a poblado de plazeres». .3

Detrás de este deseo de una «carrera de paz», en la que esperaba que alguien la encaminara, emerge otra vez el tema de la guerra. Sin embargo, pronto esta isla/destierro/segregación se convierte en una morada saludable. Los libros -los salmos de David, las obras de San Agustín, San Bernardo, Gregorio Magnoson los agentes de este cambio. Los «graciosos y santos consejos» en ellos contenidos hacen «de arboledas saludables» bajo cuya sombra su espíritu puede finalmente descansar.

También Teresa empezaba con la glosa a un salmo: «Oye fija, e acata e ynclina tu oreja, oluida el pueblo tuyo y la casa de tu padre». ${ }^{74}$ Intuye que el auténtico sentido de ese aserto se encuentra más allá de su aparente significado literal: «Esta amonestaçión e consejo de oluidar el pueblo y la casa de mi padre otra sygnificaçión trae». ${ }^{75}$ Es así cómo los oscuros versos del salmo ceden el paso a unas imágenes nítidas: la tentación del retorno a la antigua fe -la casa paterna que sus ex correligionarios no conseguían «olvidar»-y, sobre todo, la extrema vulnerabilidad del «ánima» conversa frente a los ataques de «este maldito pueblo»:

71 Pedro M. CÁTEDRA, «Prospección sobre el género consolatorio en el siglo XV», A. DEYERMOND and J. LAWRENCE (eds), Letters and society in fifteenth-century Spain. Studies presented to P.E. Russell on his eightieth birthday, The Dolphin Book Co, 1993, pp. 1-16.

${ }^{72}$ Es evidente su deuda con autores como Boecio, del que López de Ayala hizo traducir del latín al vulgar su De consolatione philosophiae o, como ha demostrado Hutton, con don Pedro de Luna, autor de otra obra que pertenecía al género consolatorio, el Libro de las consolaciones de la vida humana, dirigida a los que habían perdido el oído, enfermedad que padeció la misma Teresa. Cfr. Arboleda de los enfermos y Admiración operum Dey, op. cit., pp. 19-23.

73 Ibidem, p. 37.

${ }^{74}$ Ibidem, p. 44. «Audi, filia et vide, et inclina aurem tuam, et obliviscere populum tuum et domum patris tui» (Sal. 44,11).

75 Ibidem, p. 45.

Hispania Sacra, LXII

125, enero-junio 2010, 43-91, ISSN: 0018-215-X 
«Pero dexando en paz sus linajes por dezir la guerra que fazen en la tierra do moran, digo que ansý como en la çibdat sy se leuanta alguna parte del pueblo contra alguno, se haze grand ruydo, pero sy todo el pueblo se mueve contra él, está en asaz peligro y mal librado conbate, bien ansý por qualquier cobdiçia tenporal que contra nuestra ánima se leuante, es fecho grand ruydo en la çibdat de nuestra conçencia; e sy todo este maldito pueblo se leuanta contra el ánima nuestra, en tanto mayor peligro e peor librada ella está».76

He aquí otro escenario de guerra que culmina, como los escritos de Alonso de Cartagena, con la imagen de la conciencia sitiada, ${ }^{77}$ clavada entre un presente inmóvil y un futuro truncado: ningún progreso («virtud») puede alcanzar una «ciudad» cercada por «este negro pueblo». Situándose en el centro del alma conversa, la sobrina del obispo de Burgos prorrumpía una vez más en un grito desgarrador de rabia mal disimulada, prueba evidente de que el eco de los motines anti-conversos debía de estar aún vivo en su memoria:

«Este negro pueblo que tiene ya tomada la çibdat de nuestra conçiençia... (...); porque asý como el cabtivo está contra su voluntad en el cautiverio, así nuestra conciençia so el señorío deste pueblo peruesso»..$^{78}$

Teresa representaba el destino de un pueblo no del todo convertido e incluso reticente a la conversión. Ella cargó con el peso de esta labor inacabada, confiando en la fuerza providencial de Dios para convertir a los reacios:

«iO piadoso Señor, cómo es ynestimable la tu soberana bondat! ¡ $(\ldots)$ Ni solamente saluas a los que handan por el camino de saluaçión, mas a los que de tí se apartan e de su propio grado se van a perder; con piadosos acatamientos los costriñes y trahes por fuerça a la salut perdurable! (...) "En cabestro e freno las mexillas de aquéllos costriñes, que a tí no se allegan e quieren allegar"».79

En otro momento parece en lucha consigo misma, puesto que, aparentando justificar la necesidad de apelar a la fuerza para lograr la conversión, no sale del asombro que le produce recurrir a ella. En una glosa al Evangelio de Lucas, refiriéndose a los conversos, constataba angustiada: « ¿Y cómo entran de grado sy los lleuan por fuerça?». ${ }^{80}$

\footnotetext{
76 Ibidem, p. 46.

${ }^{77} \mathrm{La}$ «Ciudad de Dios» de Agustín y la carta a los Hebreos de Pablo (11.16 y 13.14) podrían estar presentes en la genealogía de esta alegoría que comparten tío y sobrina.

${ }^{78}$ L. J. HutTon (ed.), Arboleda de los enfermos, op. cit., p. 46.

79 Ibidem, p. 47.

${ }^{80}$ Ibidem, pp. 54-55: « «Bienaventurados aquéllos que a la çena del Cordero son llamados». Comoquier que la diuinal largueza a todos conbida e llama a esta bienaventurada çena, pero a los enfermos la dolençia rasga el manto e los haze entrar por fuerça. E aun asý lo declara aquella parábola que nuestro Señor dize en el Evangelio de aquel onbre que hizo una grand çena e llamó a muchos e como fuese fe-
} 
La escritura de Teresa avanza mediante rápidos relámpagos, mensajes precisos que hay que captar antes de que el razonamiento vuelva a sumergirse en las reflexiones morales y ascéticas que llenan la mayor parte de su tratado. Uno de estos afirmaba la predestinación del pueblo judío a la salvación. Era un mensaje importante, ${ }^{81}$ porque debilitaba uno de los argumentos clásicos del frente anticonverso: la exclusión de los cristianos nuevos del plan de redención divina. ${ }^{82}$

La tarea y el reto de Teresa fueron convencer a sus ex correligionarios de que el camino hacia la salvación pasaba por la conversión al cristianismo; ${ }^{83}$ al mismo tiempo dio a los que ya se habían convertido razones para permanecer en la fe cristiana. Una de estas fue el dolor. A través de él se renovaba la antigua promesa de amor que Yahvé hizo al pueblo elegido. Como ella recuerda, citando a Pablo, Dios castiga a los que ama. Este es esencialmente el corazón de su

cha ora de çenar enbió su syervo que dixese a los conbidados que viniesen, ca todo estaua aparejado. Los quales, por ocupaciones variables, o por mejor dezir, desuariadas, se escusaron de venir; de lo qual yndignado aquel paterfamilias, dixo al siervo: «Sal luego a las plaças y mercados y quántos enfermos, claudos y débiles hallares, costrínelos que entren, porque sea llena mi casa»». Y puntualiza: «E no dixo: «Diles que vengan», como a los primeros, mas «Hazlos entrar». Por ende paresçe que los enfermos, por fuerça son traýdos a la çena manífiça de la salut perdurable, ca la dolençia les rasga el manto e los haze entrar por la puerta de obras virtuosas, ca sy por esta puerta no entramos, no podremos llegar a tan grande colmo de onor, como es ser asentados a la mesa de la largueza diuinal. ¡O bienaventurado conventos de los enfermos! De aquéllos digo, que entran de grado donde la dolençia los lieua por fuerça y non escojen de se quedar en la calle, ¿y cómo entran de grado sy los lleuan por fuerça?». Este Evangelio de Lucas $(14,21-23)$ se convirtió en una ocasión para reflexionar sobre la absurdidad de un proceso de conversión llevado a cabo de una forma coercitiva.

${ }^{81}$ Ibidem, p. 52 y p. 67: «iO piadoso Señor! ¿Cuándo mereçí yo tanto bien? De mí se puede dezir que con méritos malos conseguí graçia; e aun graçia sobre graçia con razón la deuo llamar. Graçia es a mí la pena e sobre graçia la misericordia». La salvación divina también alcanzará a su gente: «E asý mesmo no temamos la dapnaçión con los malos, ca la misericordia de Dios nos da saluoconduto».

${ }^{82} \mathrm{Cfr}$. «El Memorial de García de Mora», op. cit., p. 104.

${ }^{83}$ En Teresa la conversión siempre es fruto del alumbramiento divino. Ya en el mismo incipit de la Arboleda de los enfermos este sentido paulino de la fe aparece con claridad: «(...) Plogo a la misericordia del muy Altýsimo alunbrarme con la luçerna de su piadosa graçia, porque pudiese poner mi nonbre en la nómina de aquellos de quien es escrito: «Los que morauan en tiniebras y en sonbra de muerte, luz les es demostrada». En con esta Luz verdadera que alumbra a todo omne que viene en este mundo, alumbrado mi entendimiento, desbaratada la niebla de mi pesada tristeza...» (la cursiva es mía), L. J. Hutton (ed.), Arboleda de los enfermos, op. cit., pp. 37-38. Cfr. también Admiraçión operum Dey: «"Domine, Domine, ut uideam lumen". Señor, que vea yo luz por la qual conosca que eres verdadera Luz y Sol de justiçia; que vea yo luz por la qual conosca en éstos públicos males los ascondidos bienes de la tu grand misericordia; que vea yo luz por la qual en éstas mis penales pasyones busque e desee grand feruor a Ti que eres verdadero Médico de las ánimas (...); que vea yo luz por la qual la mi tinebrosa e mugeril ynorançia sea alunbrada de los rayos de la tu muy alta prudençia. (...) E sy estos [los ojos] por nuestros pecados se obscuresçen e çiegan con el poluo de las terrenales cobdiçias, en tienieblas estamos e non podemos ver el camino de nuestra patria y çibdad de Iherusalem, sy Áquél que es verdadera Luz no halunbra el nuestro intendimiento. ¡O Luz eternal y Sol de justiçia, Llaue de Dauid e Cebtro de la casa de Israel, ven e libra la tribulada ánima mía de aquesta tiniebla e sonbra de muerte!». Ibidem, pp. 133-137.

Hispania Sacra, LXII

125, enero-junio 2010, 43-91, ISSN: 0018-215-X 
mensaje, con el que espera mantener a los recién convertidos en la nueva fe. En el grito del salmista y en las masacres de esos años, el sufrimiento sigue configurando su historia. Teresa lo rescata para convertirlo en una categoría del alma judeocristiana. ${ }^{84} \mathrm{Su}$ mística del dolor está al servicio de esta misión: devolver a los judeo-conversos un horizonte en el que puedan proyectar sus esperanzas de futuro, permitiéndoles también volver a encontrar sus raíces.

El modelo sólo podía ser Job, el hombre que conservó su confianza en Dios a pesar de las pruebas durísimas a las que tuvo que enfrentarse. ${ }^{85} \mathrm{El}$ sufrimiento, tiempo intermedio entre la promesa de la redención y su cumplimiento, es necesariamente un lugar de espera y ninguna virtud es más indicada que la paciencia. La elección de Job a este propósito no es casual. Este personaje del Antiguo Testamento, a quien Teresa llama el «Maestro de las Paçiençias», representa al justo que sufre sin culpa y que Dios quiere poner a prueba. Cuando todo parece perdido, debe mantenerse la fe: este es el mensaje del Libro de Job que la autora recupera.

Sin embargo, ella también se ofrece a sí misma como modelo para su gente. $\mathrm{Su}$ yo individual acaba convirtiéndose en espejo de un yo colectivo. En su enfermedad, que la llevó a un aislamiento casi completo, se reflejaba el sufrimiento de todo un pueblo. De hecho, pese al tono intimista del tratado, se percibe un halo épico, escondido entre las ambigüedades morfológicas de la obra.

Los «enfermos» que Teresa aspiraba a «curar» padecían una «dolencia» especial: 86 descender de un linaje maldito y despreciable, como había escrito García de Mora en su Memorial. A pesar de implicar a fondo su yo, indudable rasgo moderno de su obra, Teresa dio escasas noticias de sí misma en su tratado. Tal vez esta sea una prueba indirecta de que no necesitaba identificarse delante de todos aquellos con quienes compartía el «tenebroso destierro»: es decir, otros conversos como ella.

\section{«IN TERRA DESERTA, INVIA ET INAQUOSA»: LA DIFÍCIL MISIÓN DE JUAN DE ÁVILA}

Como si siguiera una corriente larga y subterránea, el salmo 44, tan presente en la escritura de la sobrina de Alonso de Cartagena, reaparece ya en el título de

${ }^{84}$ Ibidem, pp. 66-67: «E aun en loor de aqueste examen o prueva quel Señor haze a sus electos, canta la Yglesia: «Asý como oro en el fuego prouó el Señor a sus escojidos, e que asý como olocausto o sacrifiçio los reçibió»».

85 Ibidem, pp. 97 y ss.

${ }^{86}$ Sobre la importancia del background judío en la obra de Teresa de Cartagena, véase el artículo de James HusSAR, «The jewish roots of Teresa de Cartagena's Arboleda de los enfermos», La Corónica 35.1 (Fall, 2006), pp. 151-169. Sobre el mismo tema véase también M. L. GioRdANo, Apologetas de la fe. Elites conversas entre Inquisición y Patronazgo en España, op. cit., pp. 57-69. 
una obra fundamental de la literatura espiritual del siglo XVI, Avisos y reglas cristianas para los que desean servir a Dios, aprovechando en el camino espiritual. Compuestas por el Maestro Ávila, sobre aquel verso de David: "Audi, filia, et vide, et inclina aurem tuam». ${ }^{87}$ Juan de Ávila, brillante predicador y escritor del siglo XVI, tenía ascendencia judía por parte de padre.

Los orígenes del libro remontan a principios de los años treinta del siglo XVI, cuando enviaba unas cartas a su hija espiritual, doña Sancha Carrillo, la joven hermana de uno de sus primeros discípulos, don Pedro Fernández de Córdoba. A estas epístolas añadió las reflexiones elaboradas durante su estancia en la cárcel del Santo Oficio de Sevilla entre el otoño del 1532 y el verano del 1533. De aquellos meses no guardó un mal recuerdo, puesto que allí Dios le iluminó sobre «el conocimiento del misterio de nuestra redención», como prudentemente anotó Luis de Granada, sin usar la expresión censurada de «beneficio de Cristo». ${ }^{88}$

El «evangelismo radical» y cierto espíritu de independencia hacia la Inquisición, en los primeros años de su apostolado, fueron las causas de su arresto. ${ }^{89}$ En 1539, a dos años de la muerte de su asistida, el libro ya estaba listo para la imprenta..$^{90}$ La benévola insistencia del conde de Palma, Luis de Puertocarrero, patrocinador de la edición, el desconcierto causado por la circulación de ese manuscrito y las alteraciones que sufriría el texto parecieron impulsarle a imprimirlo. Aun así, la publicación del libro fue aplazada, si bien finalmente en 1556 se llegó a la publicación con el impresor complutense Juan de Brocar, pero sin licencia del autor, como se advirtió en el prólogo de la edición autorizada de 1565 .

Según Sala Balust, Juan de Ávila no hubiera publicado su obra sin incluir los oportunos ajustes de conformidad con los decretos conciliares relativos a un tema, como el de la justificación, que afectaba directamente a su libro. ${ }^{91}$ Siendo así, la publicación de 1556 se debería a la iniciativa de un incauto discípulo de Ávila. Esta explicación no convenció a Bataillon, persuadido de que la edición de 1556 había sido impresa con el consentimiento de su autor. Por eso vio en

\footnotetext{
${ }^{87}$ Cfr. Gregorio RodríGuez RIVAS, «La influencia de Teresa de Cartagena en el Audi Filia de Juan de Ávila», Archivum, XLI-XLII (1991-1992), pp. 329-337. El autor de este breve artículo se limita a observar el uso de parte de Teresa de Cartagena y de Juan de Ávila del mismo salmo, coincidencia que explica haciendo alusión al «carácter reformador de ambos escritores».

${ }^{88}$ Fray L. DE Granada, O.P., Licenciado L. MuÑoz, Vidas del padre maestro Juan de Ávila, L. Sala Balust (ed.), Juan Flors, Barcelona, 1964, pp. 93-95.

${ }^{89}$ Marcel Bataillon, «Jean d'Ávila retrouvé (à propos des publications récentes de D. Luis Sala Balust)», Bulletin Hispanique, LVII (1955), p. 16.

90 San Juan De Ávila, «Introducción biográfica», Obras completas, L. Sala Balust y F. Martín HERnÁNDEZ (eds.), BAC, Madrid, 2007, vol. I, p. 171.

${ }^{91}$ Ibidem, p. 174. 
ella una «expression peut-être imprudente, mais authentique de la pensée religieuse d'Avila à l'apogée de son action (jusque vers 1546 d'après D.Luis Sala, jusqu'en 1556 d'après nous)». ${ }^{92}$

Como es sabido, el libro fue incluido en el Índice de Valdés de 1559. Según Bataillon, a partir de ese momento, el Apóstol de Andalucía se vio obligado a desmarcarse del texto prohibido, modificando su tratado. La obra fue finalmente reimpresa por sus discípulos en 1574, es decir cinco años después de su muerte en 1569.

Importa detenerse en el primer núcleo del Audi Filia, que se remonta a los años treinta del siglo XVI, cuando el movimiento iluminista toledano y las corrientes erasmistas, aun tenazmente perseguidos, todavía no habían sido del todo derrotados. Entre 1523 y 1526 Juan de Ávila cursó sus estudios de teología en Alcalá. No sabemos cómo el rebosante erasmismo de esta universidad influyó sobre la maduración de su perfil espiritual paulino. ${ }^{93}$ Ciertamente tuvo más tarde que rendir cuenta de ello al Santo Oficio.

El mismo destino le tocó al grupo de iluminados toledanos, otros paulinos en esencia, calificados de «heterodoxos». ${ }^{44}$ Con ellos compartía la idea de la religión en espíritu, que enfatizaba la participación interior (oración mental, recogimiento) en la relación con Dios, en detrimento de la práctica de los «ritos exteriores» (oración vocal, limosnas, ayunos, mortificaciones corporales).

No obstante, su pensamiento se adelantaba con respecto a toda esta fenomenología religiosa por llevar en sus entrañas la reflexión sobre el beneficio de

${ }^{92} \mathrm{Si}$ el historiador francés consideraba auténtico el prefacio a la edición del 1556, dirigido al conde de Palma, no opinaba lo mismo del «Prólogo del autor» de la edición póstuma de 1574, en el que Ávila negaba la autoría del texto impreso en Alcalá en 1556. Según M. BATAILLON, el tono de justificación a posteriori del prólogo del 1574 revelaba la intervención de «un disciple trop bien intentionné». Cfr. «Jean d'Ávila retrouvé (à propos des publications récentes de D. Luis Sala Balust)», op. cit., pp. 22-30.

${ }^{93}$ Según Ricardo García VillosladA, Juan de Ávila llega al paulinismo no a través de Erasmo sino por la meditación y la experiencia mística. De hecho no fue el holandés quien trajo el conocimiento de San Pablo a los españoles, puesto que ellos lo leían y estudiaban desde antiguo. Cfr. I., «El paulinismo de San Juan de Ávila», Gregorianum 51(1970), pp. 617-647 (p. 623). Sobre las diferencias entre el paulinismo de Ávila y el de Erasmo, véase Melquíades ANDRÉs MARTín, «Erasmo (1466-1536) y Juan de Ávila (1500-1569): en torno a su humanismo y espiritualidad», Actas del Congreso Internacional, Madrid 27-30 noviembre 2000, Junta Episcopal «Pro Doctorado de San Juan de Ávila», Conferencia Episcopal Española, pp. 171-194.

${ }^{94}$ De aquellos procesos inquisitoriales recuerdo sólo algunos de los que han sido editados: M. ORTEga Costa, Proceso de la Inquisición contra María de Cazalla, FUE, Madrid, 1978; J. M. CARRete PARRONDO, Movimiento alumbrado y renacimiento español: proceso inquisitorial contra Luis de Beteta, Centro de Estudios judeo-cristianos, Madrid, 1980; A. SelKe, El Santo Oficio de la Inquisición: proceso de Fray Francisco Ortiz (1529-1532), Ediciones Guadarrama, Madrid, 1968; A. Hamilton, El proceso de Rodrigo de Bivar (1539), FUE, Madrid, 1979. 
Cristo. He aquí el motivo de la censura de la primera edición de 1556. Esta espiritualidad, con su enorme confianza en la gracia, instrumento de la salvación a través de la Pasión de Cristo, era para el inquisidor directamente asimilable al luteranismo. Tras la ruptura de la reforma protestante ningún tema suscitaba más interés y alarma que éste, un aspecto crucial a la hora de discernir entre los «herejes» potenciales, inquietos partidarios de la religión interior, y los defensores del culto de las obras, fieles a la devoción tradicional.

La Andalucía de Juan de Ávila se impuso firmemente en el debate espiritual desde los años cuarenta, cuando se imprimió en Sevilla primero la Suma de doctrina christiana, ${ }^{95}$ en 1545 y, al cabo de dos años, la Confesión de un pecador, que apareció como anónima en la misma ciudad. ${ }^{96}$

Por su fuerza, belleza y modernidad esta última podría considerarse el manifiesto de todo un movimiento de religión interior construido sobre la acción redentora del sacrificio de Cristo. Su autor fue Constantino Ponce de la Fuente, «la personalidad más vigorosa que dieron los conversos a la Iglesia de España en la época del Emperador». ${ }^{97}$ La fama de su elocuencia era tan grande que Carlos V lo hizo capellán y predicador suyo. Una prudencia elemental impulsó al escritor de estos tratados a elegir Portugal para la segunda edición de la Confesión, publicada en Évora en 1554, con dos escritos devocionales de Fray Luis de Granada, discípulo de Juan de Ávila, a pesar de llevar hábito de dominico. ${ }^{98}$ Es una prueba evidente de los lazos que unían la escuela del beneficio de Cristo con la del Apóstol de Andalucía, ambas deudoras de las enseñanzas de Erasmo y de Juan de Valdés. ${ }^{99}$

Sevilla tuvo la suerte de gozar de la predicación de Constantino Ponce de la Fuente. Allí fue titular desde 1557 de la «canonjía magistral» de la Iglesia hispalense, cargo obtenido con la aprobación unánime de los canónigos sevillanos, a pesar de su origen judío y de su antigua amistad con el doctor Egidio. Con este nombre se conocía a Juan Gil, un clérigo procesado por la Inquisición

95 No sería extraño que esta obra fuera escrita para los niños del Colegio de la Doctrina, conocido foco del luteranismo sevillano, donde Constantino tenía una cátedra de Sagrada Escritura. También el padre Ávila estuvo vinculado con dicha institución, que recibió cuantiosas donaciones de parte de la condesa doña Blanca de Guzmán, madre de don Diego de Guzmán, discípulo del religioso. Cfr. Juan DE ÁvILA, «Introducción biográfica», op . cit., vol. I, p. 181, nota 39.

${ }^{96}$ M. Paz Aspe Ansa (ed.), Constantino Ponce de la Fuente. Confesión de un pecador, Universidad Pontificia de Salamanca, FUE, Madrid, pp. 23-24.

${ }_{97}$ M. Bataillon, Erasmo y España, Fondo de Cultura Económica, México, 1995, p. 523.

98 Confission de un pecador delante de Iesu Christo redemptor y juez de los hombres, compuesta por el doctor Constantino. Añadieronse dos meditaciones para antes de la sagrada comunion compuestas por el padre Fray Luys de Granada. Andrés de Burgos impressor, Évora 2 de agosto de 1554.

${ }^{99}$ M. Bataillon, Erasmo y España., op. cit., pp. 494 y ss. Cfr., también, José Ignacio TellecheA, «Juan de Valdés y Bartolomé de Carranza», Revista Española de Teología, t. XXI (1961), Cuad. 3º, pp. 289-324.

Hispania Sacra, LXII

125, enero-junio 2010, 43-91, ISSN: 0018-215-X 
como sospechoso de «luteranismo» y protagonista en 1552 de una clamorosa retratación de sus «errores».

La precaución de publicar fuera de España no evitó que todas sus obras fueran incluidas en el Índice de Valdés en 1559. Por aquel entonces ya estaba en la cárcel inquisitorial, donde ingresó en el verano del año anterior. Al cabo de dos años, una enfermedad, contraída durante los meses de prisión, acabó con su vida antes de que se celebrara el auto de fe del 22 de diciembre de $1560 .{ }^{100}$ En la plaza de San Francisco, la misma en la que tuvo lugar el primer auto de fe contra los «luteranos» sevillanos un año antes, el Santo Oficio intentó enterrar la memoria del famoso predicador entregando a la hoguera sus despojos.

El mismo año en que se publicó el Audi Filia, Fray Luis de Granada hizo imprimir en Lisboa su Guía de pecadores, otro manifiesto sobre la obra redentora de Cristo. Con la aparición de los Comentarios al catechismo christiano de Bartolomé de Carranza, dos años más tarde, se añadió una figura clave al gran fresco del beneficio de Cristo. ${ }^{101}$ El vínculo con Juan de Ávila fue otra vez pro-

100 Cfr. N. CAStrillo Benito, El «Reginaldo Montano»: primer libro polémico contra la Inquisición española, CSIC, Centro de Estudios Inquisitoriales, Madrid, 1991, p. 451.

${ }^{101}$ La expresión «beneficio de Cristo» apareció por primera vez en Melanchthon, en 1520, el cual recuperó plenamente la idea paulina de un Dios misericordioso que se hace cargo de los pecados de los hombres a través de Cristo. Este concepto se convirtió, como se sabe, en el centro de la cristología y ética protestante. En su formulación estaría implicado Erasmo, que Melanchthon pudo conocer y apreciar en su edición del Nuevo Testamento, publicado en Basilea en 1516 con el título Novum Instrumentum. La lectura de las notas filológicas, que el humanista redactó para aquel texto, parecen haber sugerido al discípulo de Lutero la idea de llamar «beneficium Christi» el don supremo de la salvación mediante la fe. Cfr. Salvatore CAPONETTO, «Erasmo e la genesi dell'espressione «Beneficio di Cristo»», Annali della Scuola Normale Superiore di Pisa, Vol. XXXVII (1968), Fasc. III-IV, p. 271-274. Cfr., del mismo autor, Benedetto da Mantova. Il beneficio di Cristo. Con le versioni del secolo XVI. Documenti e testimonianze, G. C. Sansoni, Firenze, The Newberry Library, Chicago, 1972.

Desde entonces esa expresión hizo fortuna en Italia, donde Juan de Valdés, exiliado en Nápoles, la usaba en sus conversaciones y en sus escritos, hasta aparecer en la más famosa obra de la Reforma en Italia, publicada en 1543 en Venecia con el título «Trattato utilissimo del Beneficio di Giesù Cristo crocifisso verso i cristiani» del monje benedictino don Benedetto Fontanini da Mantova. El recorrido del aquel término acabó en España, donde fray Luis de Granada lo utilizó para referirse al «misterio de Cristo» en la biografía de su maestro. Por esta razón -concluye Villoslada- la palabra «sintetizadora «beneficio» (de Cristo)» no sería de Juan de Ávila, sino del propio biógrafo, el cual la aprendió en el círculo espiritual de Bartolomé de Carranza, donde había llegado desde Nápoles, y allí, a su vez, desde Wittemberg. Cfr. Ricardo García Villoslada, El paulinismo de Juan de Ávila, op. cit., p. 640. Una opinión similar había sido expresada por D. De SANTA TERESA, Juan de Valdés. Su pensamiento religioso y las corrientes espirituales de su tiempo, Roma, 1957.

Sin embargo, el concepto del beneficio de Cristo está presente en el Audi Filia, prescindiendo del hecho de que aparezca o no su expresión literal. Además, hay que tener en cuenta, como advirtió Francisco MárqueZ ViLlanueVA, que «la obra de san Juan de Ávila está fuertemente autocensurada y ha de ser leída, por tanto, con una profunda atención a matices y entrelíneas». Cfr. I., «Vida y escritos de San Juan de Ávila a la luz de sus tiempos», Actas del Congreso Internacional, op. cit., pp. 77-98, (p. 81). 
porcionado por Fray Luis de Granada, quien había dado a conocer la espiritualidad avilina al arzobispo de Toledo. ${ }^{102}$

Desde el punto de vista de los contenidos parece entonces confirmado el sólido anclaje del Audi filia entre las temáticas espirituales más candentes del Quinientos. Desde la óptica de su construcción interna, en cambio, recuerda una estrategia antigua: como el Oracional y la glosa al salmo Judica me Deus de Alonso de Cartagena, el tratado de Ávila era un texto con más de un nivel de lectura. En él, superpuesto al planteamiento oficial, de carácter doctrinal, se despliega otro que, como una red que se dilata o se contrae, filtra entre sus mallas una serie coordinada y coherente de significados, dejando aflorar un mensaje vibrante e irreverente. ${ }^{103}$ El Apóstol de Andalucía contaba ya con un público propio, por esta razón no tuvo necesidad de reunir a un auditorio, ${ }^{104}$ como quizá debió de hacer Alonso de Cartagena. Aun así, la tarea no fue menos ardua porque estaba en juego la supervivencia física de su «pequeña Iglesia de discípulos». 105

En Sevilla, adonde Ávila fue a predicar en 1526 y en la que se quedó durante los siguientes nueve años, ${ }^{106}$ la Inquisición seguía persiguiendo a los conver-

Sobre la presencia del tema del beneficio de Cristo en la obra de Juan de Ávila, véase M. ANDRÉs Martín, Juan de Ávila, maestro de espiritualidad, BAC, Madrid, 1997, pp. 95-100. Para este autor, el beneficio de Cristo no es un concepto de origen italiano sino complutense, en el que los conversos aportaron su inquietud de neófitos: «Es además la respuesta más honda de los auténticos conversos judíos al cristianismo frente a la negación de la divinidad de Jesucristo de sus antiguos hermanos en religión: expresar claramente su fe en los misterios de la encarnación, muerte y resurrección del Salvador».

Un punto de referencia imprescindible sobre este tema es representado por la obra de A. PROSPERI, L'eresia del Libro grande: storia di Giorgio Siculo e della sua setta, Feltrinelli, Milano, 2001, pp. 382388; cfr. del mismo autor con C. GINZBURG, Giochi di pazienza: un seminario sul beneficio di Cristo, Einaudi, Torino, 1975 y M. Firpo, Tra alumbrados e «spirituali». Studi su Juan de Valdés e il valdesianesimo nella crisi religiosa del '500 italiano, Leo S. Olschki Editore, Firenze, 1990.

${ }^{102}$ San Juan DE ÁvILA, «Introducción biográfica», op. cit., vol. I, pp. 183-185.

${ }^{103}$ Durante los años en los que Juan de Ávila frecuentó Alcalá, esta universidad se afirmó como la sede de la mayor innovación en los estudios de las letras sagradas. De allí surgió la corriente de los «escrituristas», que quería reconstruir el texto original de la Biblia siguiendo su sentido literal y basándose en el conocimiento del griego, hebreo y siriaco. Estas novedades llegaron también a Salamanca, donde entraron en conflicto con los partidarios de la interpretación escolástica de la Biblia, fieles a la opinión de los Padres de la Iglesia. Según T. Herrero del Collado, el «conocimiento vasto y científico» de las Sagradas Escrituras y el interés por la interpretación literal sitúan al maestro Ávila sin duda dentro de la corriente de los «escrituristas», aunque no dejó de practicar la interpretación alegórica de la Biblia. Cfr. I., Pastoral bíblica del maestro Juan de Ávila, Imprenta F. Román, Granada, 1961, pp. 32-33.

104 Sobre la importancia de la creación de un auditorio para los escritores del siglo XV y la función de la literatura como «congregación de oyentes», véase J. MARICHAL, La voluntad del estilo. Teoría e historia del ensayismo hispánico, Revista de Occidente Ed., Madrid, 1971, pp. 27-37.

105 Marcel BataILlon, «Jean d'Avila retrouvé», op. cit., p. 32.

${ }^{106}$ Sobre la estancia sevillana de Ávila, véase S. PASTORE, Il Vangelo e la spada. L'Inquisizione di Castiglia e i suoi critici (1460-1598), Edizioni di Storia e Letteratura, Roma, 2003, pp. 141-156.

Hispania Sacra, LXII

125, enero-junio 2010, 43-91, ISSN: 0018-215-X 
sos desde 1481.107 Por esta razón el Audi Filia está indisolublemente ligado con la inmensa labor apostólica y misionera desarrollada por Juan de Ávila en Sevilla y en su arzobispado, luego en Córdoba y Granada, y culminada finalmente con la creación del colegio universitario de Baeza. Muchos entre sus estudiantes y profesores eran cristianos nuevos. Los años en los que se gestó ese tratado coincidieron con un periodo de gran actividad, tal vez el momento más arrollador de ese «imitateur moderne de Saint Paul», 108 hasta que las enfermedades se hicieran sentir y le obligaran a llevar una vida más retirada.

Como había hecho el obispo de Burgos, también el Apóstol de Andalucía fundamentaba su discurso en un denso entramado de citas del Antiguo y Nuevo Testamento. ${ }^{109}$ Además, la sabiduría heredada de una tradición que había reflexionado largamente sobre estos temas le permitía poner en relación conceptos tan aparentemente inconciliables como los de libre albedrío y gracia divina. ${ }^{110}$ El objetivo no era meramente especulativo, puesto que no podía serlo en España, donde la literatura doctrinal entre los siglos XV y XVI a menudo fue impulsada por razones vitales, concretamente relacionadas con el desbarajuste personal de quien cruzaba distintas vivencias religiosas. La mirada, entonces, seguía dirigida a construir una simbólica «ciudad de nuestra conciencia», pero contando esta vez con un nuevo y sólido pilar: el beneficio de Cristo. Mientras que en el Cuatrocientos, en nombre del concepto paulino de cuerpo místico, se pudo deslegitimar la acción de quienes perseguían a los conversos, un siglo más tarde, con Juan de Ávila, fue la gracia santificante otorgada por la muerte de Jesús en la cruz lo que proporcionó una nueva arma espiritual para poner en entredicho el poder inquisitorial. ${ }^{111}$

107 J. GIL, Los conversos y la Inquisición sevillana, Universidad de Sevilla, 2000, vol. I. Cfr., también, Klaus WAGNER, «La Inquisición en Sevilla (1481-1524). Notas al margen de las Actas notariales del Archivo de Protocolos de Sevilla referentes a los autos celebrados en dicha ciudad», en Homenaje al prof. Carriazo, Facultad de Filosofía y Letras, Universidad de Sevilla, 1973, vol. III, pp. 441-460.

108 Así Marcel BatAiLlon acreditaba al Ávila paulino esbozado por Luis de Granada en la biografía de su maestro. Cfr. «Jean d'Avila retrouvé», op. cit., p. 43.

109 El tema del biblismo de Ávila, evidenciado por las numerosísimas citas del Antiguo y Nuevo Testamento presentes en sus obras y por el profundo conocimiento de las epístolas paulinas, que según sus biógrafos sabía «de coro», merecería más atención de la que ha recibido hasta ahora. Según T. HERRERO DEL COLLADO, este estilo avilino de establecer relaciones entre Antiguo y Nuevo Testamento se debería a la influencia de la época y de los «sectores en que dominaba el sentido alegórico y figurista» de interpretación de las Escrituras. Cfr. I., Pastoral bíblica del maestro Juan de Ávila, op . cit., p. 218.

110 Cfr. J. De Dios Mendoza Negrillo, Fortuna y Providencia en la literatura castellana del siglo XV, Real Academia Española, Madrid, 1973.

${ }^{111}$ M. L. Giondano, Apologetas de la fe, op. cit., pp. 243-244. 
«¡OH JUdEA Y HIERUSALEM, NO QUERÁIS TEMER NI HABER MIEDO!»

Como buen epígono de la «escuela alegórica» de los Cartagena, ${ }^{112}$ Ávila vuelve a utilizar una modalidad comunicativa que era ya un código bien ensayado. La alegoría se mostraba, sin embargo, menos triunfalista y más cauta. Precisamente por la prudencia que requerían los tiempos se había hecho más sutil. Serpenteando entre los pliegues del discurso espiritual, afloraba incautamente en rápidos despuntes antes de volver a sumergirse en el obstinado paulinismo del texto. La alegoría, por lo tanto, envuelve toda la materia del libro y, lejos de ser un discurso superpuesto, acaba convirtiéndose en su respiración más honda.

Seguimos las palabras del Audi Filia desde el principio. Toda su glosa al salmo 44 es un homenaje al tema paulino de la fides ex auditu (Rom.10, 17). He aquí, en este consagrado topo bíblico, el recurso argumental al que vincula la lectura alegórica del salmo. ${ }^{113}$

Los versos del salmo, «Oye, hija, y ve, e inclina tu oreja, y olvida tu pueblo y la casa de tu padre», contenían una invitación a abrir el oído «a lo de dentro» y a cerrarlo frente al mundanal ruido. Había que desconfiar sobre todo de las palabras que embaucan como «sirenas» hasta «matar a sus oyentes». ${ }^{114}$ No había que escuchar la «humana mentira» que quiere «cegar o hacer desmayar al caballero cristiano», porque «ahora halague, ahora persiga, ahora prometa, ahora amenace, ahora espante, (...) en todo se engaña y quiere engañar». ${ }^{115}$ Es difícil no pensar en la Inquisición leyendo estas palabras.

Poco después encontramos una de las primeras grandes alegorías del escrito, toda una apuesta por una convivencia pacifica entre conversos y cristianos viejos. La metáfora se expresa a través de unas eficaces imágenes evocadas por la profecía de Isaías 11,6: lobo y cordero, oso y león llegarán a comer juntos. ${ }^{116}$ En un futuro no muy lejano, los que se han convertido en enemigos, «dejada su guerra», volverán a vivir en paz unos con otros (Ps. 54,14-15). El «hombre interior» y el

112 Cfr. J. AMAdor DE Los Ríos, Historia de la literatura española, Madrid, 1865, vol. 6.

${ }^{113}$ Sobre los significados alegóricos de la sordera en el Antiguo Testamento véase James Hussar, «The jewish roots of Teresa de Cartagena's Arboleda de los enfermos», op. cit.

${ }^{114}$ San Juan DE ÁvILA, Obras completas, op. cit., vol I, p. 409.

115 Ibidem, p. 411.

116 Ibidem, p. 419. También Alonso de Cartagena comentó el mismo pasaje del profeta Isaías (11, 6), para aludir al contraste entre la convivencia del lobo con el cordero o la del leopardo con el cabrito. Con estas imágenes alegorizaba la unión dentro una misma Iglesia de la desenfrenada beligerancia de los gentiles, fuertes en las armas, con la mansedumbre del pueblo de la ley, «Quid ergo aliud est lupum cum agno simul habitare aut pardum cum edo accubare nisi effrenatam bellicositatem gentilium et strenuitatem armorum mansuetudini populi legalis intra unam ecclesiam coniungi.» Cfr. Alonso DE CARTAGENA, Defensorium unitatis christianae, op. cit., pp. 140-141.

Hispania Sacra, LXII

125, enero-junio 2010, 43-91, ISSN: 0018-215-X 
«hombre exterior», unidos como si fueran una sola alma, «andan en uno en la casa de Dios». Ellos serán «tan amigos» que si «el interior come castidad, orar, ayunar y velar, y otros santos ejercicios, hallando muchas dulzura en ellos, también el hombre exterior hace estas obras, y le saben como dulce manjar».

Ávila continúa utilizando la categoría del «hombre exterior» para referirse a los cristianos viejos. Aunque no se mencionen directamente, se reconocen en los rasgos de quienes habían sido cegados por las «buenas obras». A estos últimos, pagados de sí mismos, contraponía la figura turbada y sin conciencia del converso:

«[El demonio] a unos [los cristianos viejos] ciega con las buenas obras, poniéndoselas delante y escondiéndoles sus señales, y así los engaña haciéndoles ensoberbecer; y a otros [los cristianos nuevos] escóndeles que no se acuerden de sus bienes que por gracia de Dios ha hecho, y tráeles a la memoria sus males, y así los derriba. A los unos díceles que sus bienes son muchos y sus pecados pocos y livianos; a los otros, que los bienes que han hecho son pocos y llenos de falta, y sus males muchos y grandes». ${ }^{117}$

El siguiente fragmento del tratado constituye uno de los momentos más altos de esa conciencia cristiana que vio en el beneficio de Cristo un instrumento de crítica a un poder arbitrario y mortífero, como debió parecer el Santo Oficio. Dice así:

«Si el demonio nos quisiere turbar con gravarnos los pecados que hemos hecho, miremos que ni él es la parte ofendida, ni tampoco el juez. Dios es a quien ofendemos cuando pecamos, y él es el que ha de juzgar a hombres y demonios, y, por tanto, no nos turbe que el acusador acuse, mas consuélenos que el que es parte y juez nos perdona y absuelve. Y esto dice San Pablo así: Si Dios con nos, ¿Quién será contra nos? El cual a su propio Hijo no perdonó, mas por todos nosotros lo entregó. Pues, ¿cómo es posible que dándonos a su Hijo, no nos haya dado todas las cosas? ¿Quién acusará contra los hijos de Dios? Dios es el que justifica, ¿Quién habrá que condene? (Rom. 8,31-34). (...) Y pues Dios nos perdona, ¿qué aprovecha que el demonio dé voces, pidiendo justicia?».118

Juan de Ávila recordaba que semejante «demonio», alusión evidente a la justicia inquisitorial, no tenía jurisdicción sobre los cristianos que habían sido salvados por el «Dios que justifica» y por los «muchos merecimientos de Cristo». Volverá a explicarlo a través de la potente imagen bíblica del Éxodo, suprimida en la versión de 1574: ${ }^{119}$ el faraón y su ejército murieron ahogados en el mar Rojo así como los pecados de los hombres fueron ahogados en la sangre y merecimientos del Redentor. «Cerramos entonces las orejas a este lenguaje»,

\footnotetext{
117 San Juan DE ÁvILA, Obras completas, op. cit., vol. I, p. 423.

118 Ibidem, p. 424.

119 Ibidem, p. 387.
} 
amonestaba, para concluir con los versos de David: «Siendo el Señor mi ayudador, yo despreciaré a mis enemigos». (Salmos 117, 7). ${ }^{120}$

Ávila no había acabado todas sus instrucciones al respecto cuando, desazonado pero no desesperado, sugirió una última y definitiva respuesta para aquel «demonio»y para su «lenguaje»: el silencio del justo.

«Entonces hemos de hacer lo que hacía David: Yo, como sordo, no oía; y como mudo, que no abre su boca. (Sal 37,14) (...) Y pues no podemos dejar de oír este lenguaje, pues que el demonio, aunque no queramos, nos trae estos pensamientos y hablas tan malas, seamos a lo menos como quien no oye (...) Y por esto la mejor respuesta es no responder, aunque nos parezca que teníamos qué, mas una vez al día decir que creemos lo que cree la santa Iglesia Romana (...) y decir al Señor lo que está escripto: Señor, fuerza padezco, responded vos por mí (Is. 38,14) (...) Por lo cual dice la Sagrada Escriptura: Vosotros callaréis y el Señor peleará por vosotros (Éx 14,14). De manera que nuestro pelear no es a solas manos, mas muy más principalmente con invocar al Señor todopoderoso, el cual por nosotros pelea. Y esto es lo que dice el profeta Esaías: En silencio y esperanza será vuestra fortaleza» (Is, 30,15). ${ }^{121}$

A la luz del dramatismo de estas palabras parece verosímil que pudiera haber dicho, tal y como se le acusó en el proceso inquisitorial, que los quemados por la Inquisición eran mártires o que junto a la Iglesia de «la comunión de los santos» existía una «iglesia del demonio». ${ }^{122}$ Aquí a duras penas lograba contener sus sentimientos. Amargado, constataba que no bastaba con repetir «más de una vez al día que creemos lo que cree la santa Iglesia Romana». Como si de una melodía in crescendo se tratara, también su ataque alcanzaba el momento culminante. Afilaba la pluma como una lanza cuando denunciaba con venenosa ironía la «desordenada codicia de los devotos sentimientos del ánima», ${ }^{23}$ con un evidente desprecio, de riguroso cuño iluministico-erasmiano, hacia toda devoción ostentosa y estereotipada.

No renunciaba, sin embargo, a dar algún consejo para lograr «el vencimiento de esta batalla». De modo que reaparece la sombra de la guerra en esta invitación a deshacerse de los elementos irreductibles del judaísmo:

«(...) Echemos de nosotros tanta fruta perdida, que estaba colgada de nuestra secreta codicia, y cogeremos otros nuevos frutos de gozo y paz».124

120 Ibidem, p. 425.

${ }^{121}$ Ibidem, p. 426.

122 Se le acusaba de hacer dicho que sería una herejía decir «Creo en la santa Iglesia» sin añadir: «y en la comunión de los santos», porque había también una iglesia del demonio. El proceso inquisitorial contra Juan de Ávila se ha perdido. Disponemos de un extracto oficial del mismo, descubierto entre los papeles del Archivo de la Congregación de Ritos por Camillo María ABAD, «El proceso inquisitorial contra el beato Juan de Ávila», Miscelánea Comillas, 6 (1946), pp. 95-167.

123 San Juan DE ÁvILA, Obras completas, op. cit., vol. I, p. 427.

124 Ibidem, p. 428. 
Otra vez se desviaba de la senda del discurso oficial, dirigido a su asistida, para infundir ánimo a sus lectores, como lo haría un general antes de un combate: «iOh Judea y Hierusalem, no queráis temer ni haber miedo!». Recordando las palabras de Pablo, aseguraba que otras veces el Señor les había concedido la victoria, liberándoles de peligros mortales. ${ }^{125}$

«¿Qué temeremos de este león que busca a quien trague, pues nos defiende el fuerte león de Judá, el cual siempre vence? (Ap. 5,5). Y si el demonio nos cerca, Cristo está aparejado para pelear por nosotros; empero, si no perdemos la fe, como se escribe en la Santa Escritura, la cual cuenta que, como contra el rey Josafat viniese innumerable copia de gente, tanto que él fue lleno de miedo, y dejando sus pocas fuerzas por las muchas de sus enemigos, diose a pedir favor al Omnipotente. Y respondióle Dios por boca de un profeta de esta manera: Esto dice el Señor Dios: No queráis temer ni haber miedo de esta muchedumbre, porque no es la guerra vuestra más del Señor (2Crón 20,15). No seréis vosotros los que habéis de pelear, mas solamente estad con confianza, y veréis el socorro del Señor sobre vosotros. ¡Oh Judea y Hierusalem, no queráis temer ni haber miedo, que mañana saldréis y el Señor será con vosotros!».126

No era la primera vez que animaba a los suyos a confiar en Dios para vencer el miedo de las persecuciones del que eran víctimas. Los ataques inquisitoriales desencadenados en 1549 en contra de la comunidad de cristianos nuevos de Úbeda acabaron involucrando a sus amigos y discípulos del Colegio de Baeza, la universidad «conversa» fundada poco menos de una década antes, que ahora se encontraba en el ojo del huracán. Pensando en ellos dijo lo siguiente:

«(...) Olvidado me había, amados hermanos, de lo que comenzado había a hablaros, rogándoos y amonestándoos de parte de Cristo que no os turbéis y no os maravilléis, (...) con las persecuciones o sombra de ellas que nos han venido. Porque esto no ha sido sino una prueba o examen de la lección que cinco o seis años ha que leemos diciendo: «iPadecer! ¡Padecer por amor de Cristo!»(...) Mas confortaos en el Señor y en el poder de su fortaleza (Ef. 6,10), que os ama para querer defenderos; y aunque es uno, puede más de todos, pues que es omnipotente (...). Ni os espanten las amenazas de quien os persigue, porque de mí os digo que no tengo en un cabello cuanto amenazan, porque no estoy sino en manos de Cristo.

Y tengo gran compasión de su ceguedad, porque el Evangelio de Cristo, que yo en ese pueblo he predicado, está cubierto a los ojos de ellos...».127

125 Ibidem, p. 433: «Y esto afirma San Pablo haberle acaecido, diciendo: No quiero ignoréis, hermanos, nuestra tribulación en Asia, en que sobremanera y sobre nuestras fuerzas fuimos atribulados, tanto que nos daba pena el vivir, y nosotros, dentro de nosotros, tuvimos por cierto que no habíamos de escapar de la muerte. Y esto acaeció así, para que no tengamos fiucia en nosotros, mas en Dios, que da vida a los muertos; el cual nos libró de tan grandes peligros, y en el que esperamos que también nos librará de aquí adelante» (2 Cor. 1, 8-10).

${ }^{126}$ Ibidem, p. 432.

127 Carta n. 58, San Juan DE Ávila, Obras completas, op. cit., vol. IV., pp. 270-271. Negando crédito a la datación oficial de esta epístola, fechada en torno al 1532, Bataillon adelantó la hipótesis de 
«EL REMEDIO PARA ESTA MANCHA»

A lo largo de su vida Juan de Ávila tropezó con el problema de su ascendencia judía y de los «muchos cristianos nuevos» que le seguían. ${ }^{128}$ De hecho, cuando se trató de admitir en la Compañía de Jesús a los suyos no fueron pocas las tensiones causadas por la mentalidad persecutoria de la «limpieza de sangre». ${ }^{129}$ Tensiones que se vislumbran, por ejemplo, en la misma decisión de no tomar el hábito de jesuita. Y visto que el Apóstol de Andalucía confió a esta orden el futuro de su labor apostólica y didáctica, pensamos que tal vez le causaría cierta tristeza ver que allí algunos hacían «distinçión de linages y sangre». 130

El Santo Oficio tenía bajo inspección al colegio de Baeza, sospechoso de ser un baluarte de cristianos nuevos. En torno al 1552 arrestó al doctor Bernardino de Carleval, columna de esa universidad, y a otro de sus profesores, el converso doctor Gaspar Loarte, y se preparaba para detener también a don Diego de Guzmán. Este futuro miembro de la Compañía de Jesús era hijo del conde de Bailén y de doña Blanca de Guzmán y sobrino del que fuera arzobispo de Sevilla, Alonso de Manrique. Su hermano, don Juan Ponce de León, fue un personaje de primer orden en el mapa de la «herejía luterana» de la ciudad hispalense,

que estuviera vinculada con el clima de persecución creado a raíz de unos procesos inquisitoriales y unos arrestos masivos, llevados a cabo por el tribunal de Córdoba en la ciudad de Úbeda a partir de 1549. El historiador francés aportaba como prueba el descubrimiento de unas cartas de don Diego de Guzmán, en las que este discípulo de Juan de Ávila -«incorrigible défenseur des persécutés»- protestaba contra la actividad del aquel tribunal dirigida básicamente contra los conversos. Cfr. Marcel BATAILlON, «Jean d'Ávila retrouvé (à propos des publications récentes de D. Luis Sala Balust)», op. cit., pp. 9-15. Sobre los conversos de Úbeda véase el reciente estudio de P. A. Porras ArboledA, Las comunidades conversas de Úbeda y Baeza en el siglo XVI, Diputación provincial de Jaén, 2008.

${ }^{128}$ Una carta del jesuita Nadal constituye, según Sala Balust, el mejor retrato que tenemos de Juan de Ávila: «Es buen hombre, y yo me satisfacía mucho como le veía acertar en los puntos etiam muy particulares de nuestro modo de vivir. Síguenle muchos cristianos nuevos, no sólo en los que siguen su consejo, de diversos estados, mas también de los que le siguen modo semejante al nuestro, en los cuales ha tenido alguna persecución, y tiene actualmente», Juan DE ÁvILA, «Introducción biográfica», op . cit., vol. I, p. 150.

129 Ibidem, pp. 131 y ss.

${ }^{130}$ MHSI, Ribadeneira, La Editorial Ibérica, Matriti, 1923, Vol. II, p. 381: «(...) Esto [excluir a los judíos de la Compañía] es contra el paresçer de los hombres más santos, más religiosos, más graues amigos de la Compañía. Más santos, porque el P. Mtro Áuila dixo que por dos cosas se podría perder la Compañía; la primera por admitir a ella mucha turba; la segunda, por haçer distinçión de linages y sangre». A propósito del problema de los «estatutos de limpieza de sangre» en la Compañía de Jesús, una referencia obligada es el ensayo de Eusebio REY, «San Ignacio de Loyola y el problema de los «cristianos nuevos»», Razón y Fe, 153 (1956), pp. 173-204; sobre el tema véase también A. A. SicrofF, Les controverses des statuts de "pureté de sang» en Espagne du XV au XVII siècle, Didier, Paris, 1960, pp. 270-290 y Francisco DE BORJA MEDINA, «Ignacio de Loyola y la «limpieza de sangre»», en Ignacio de Loyola y su tiempo, Congreso Internacional de Historia, 9-13 setiembre 1991, Universidad de Deusto, Bilbao, pp. 579-615.

Hispania Sacra, LXII

125, enero-junio 2010, 43-91, ISSN: 0018-215-X 
donde fue quemado en 1559. Don Diego de Guzmán llegó a llamar la atención del tribunal inquisitorial por su enérgica y reiterada defensa ante los inquisidores de los conversos de Úbeda, a su parecer víctimas de una arbitraria campaña de delaciones y persecuciones del Santo Oficio de Córdoba. ${ }^{131}$ A sacarle del peligro inminente fue un oportuno desplazamiento hacia tierras del Norte, donde el padre Francisco de Borja le acogió, junto con su compañero inseparable el doctor Gaspar Loarte, que mientras tanto había salido libre del Santo Oficio, como también Carleval poco después. Aun así, el ambiente era tan tenso que Juan de Ávila consideró oportuno dosificar el ingreso de sus discípulos en la Compañía para que no «dijesen que era sinagoga». ${ }^{132}$

No puede sorprender entonces que se animara a deslegitimar cualquier justificación teológica de la «limpieza de sangre». La ocasión se presentó cuando tuvo que explicar a doña Sancha Carrillo el significado de la fe. Por ser un don de Dios, como dijo el Apóstol, la fe no es algo de lo que uno se pueda jactar, puesto que no se hereda con la sangre ni con la tradición familiar. Por eso «la verdadera fe cristiana no está arrimada a decir: "nací de cristianos", o "veo a otros ser cristianos, y por eso soy cristiano"».133 Esta página memorable del tratado apareció mutilada en la edición de $1574,{ }^{134}$ ¿tal vez para no «herir los sentimientos de los cristianos viejos orgullosos de serlo»?135

Del orgullo de estos últimos tampoco pareció preocuparse Carranza, que recordaba las palabras de S. Pablo, a quien llamaba «padre de mucha gente» por haber acogido a todos los pueblos. Así escribía en sus Comentarios: «Recibimos la gracia como hijos de Abraham, no por sangre, sino por imitación y descendencia de su fe». ${ }^{136}$

Ávila seguía acusando. La acción de los Inquisidores, «los que siendo amados nos matan», ${ }^{137}$ impide el perdón divino, desembocando inevitablemente en

${ }^{131}$ Cfr. Marcel Bataillon, Jean d'Ávila retrouvé, op. cit. Sobre estos procesos ha vuelto a llamar la atención Stefania PASTORE, «Tra conversos, gesuiti e Inquisizione: Diego de Guzmán e i processi di Úbeda (1549-1552)», G. PAOLIN, (ed.) Inquisizioni: percorsi di ricerca, Trieste, 2002, pp. 215-251.

132 MHSI, Ep. mixt IV, pp. 418-420, citada por L. SALA BALUST, San Juan DE ÁvILA, «Introducción biográfica», op . cit., vol. I, pp. 152-153.

133 Resumo aquí los pasajes fundamentales de su argumentación: la fe, «fundamento de todos los bienes», no es «enseñanza humana, más divina», puesto que «no la enseñó carne ni sangre, mas el Padre que está en los cielos, a cuyas obras y poder no hay quien resista. Esta hace a los creyentes hijos de Dios, como dice san Pablo: Todos vosotros sois hijos de Dios por la fe que tenéis en Jesucristo». Juan DE ÁvILA, Obras completas, op., cit., vol. I, pp. 436-437.

134 Ibidem, p. 626

135 M. BATAILlON, «Jean d'Avila retrouvé», op. cit., p. 30.

136 B. Carranza de Miranda, Comentarios sobre el Catechismo Christiano, J. I. TellecheA IDIGORAS (ed.), BAC, Madrid, 1972, p. 197.

137 «Nuestra muerte es apartarnos de Dios, y por eso nuestro tornar a Él es vivir. A lo cual Dios nos convida, no poniendo sus ojos de ira sobre su hechura, que somos nosotros, mas principalmente contra 
una lógica de muerte. Así lo recuerdan las palabras del profeta que cita a continuación: «¿Por qué queréis morir? Sabed que yo no quiero la muerte del pecador, mas que se convierta y viva» $($ Ez. 33,11$) .{ }^{138}$

Sondeando toda la profundidad del concepto de beneficio de Cristo, consiguió extraer de allí el origen incuestionable del rescate converso. La «carne medicinal» de Jesús era el único remedio para sacar la «mancha», y no sólo la del pecado, según parece, y restituir así «blancura» a las almas. ${ }^{139}$ Con este nuevo pasaporte espiritual nadie hubiera podido negar a su gente la entrada en la ciudadela cristiana.

\section{«VENIR DE ELLOS Y PRINCIPALMENTE A ELLOS EL QUE ES EL SALVADOR»}

Los principales destinatarios del mensaje cristiano habían sido los judíos. Juan de Ávila estaba firmemente convencido de eso y de la oportunidad de recordarlo. Un fragmento del Evangelio de Lucas le ofreció la ocasión de lanzar una exegesis con la que quiso demostrar su tesis. No era verdad que Cristo había sido puesto «a la vista de todos». (Lc. 2, 29-32). Eso acaeció después de muerto, cuando los apóstoles difundieron su mensaje por el mundo. Antes de ese momento Jesús fue «luz no sólo de los judíos, que creyeron en El y a los cuales fue enviado», sino también de los gentiles que vivían en la idolatría. La

los pecados que hacemos. Estos quiere Dios destruir, si nosotros no le impidiésemos, e impedímosle cuando amamos nuestros pecados, dando vida con nuestro amor a los que siendo amados, nos matan. Y es tanta la gana que esta bondad tiene de destruir nuestra maldad, para que su hechura no quede destruida, que, cuando quiera y cuantas veces quisiere, y de cuantas maldades hubiere hecho, quiera pedir al Señor que las destruya, está el Señor aparejado para destruirlas, perdonando lo que merecemos, sanando lo que enfermamos, enderezando lo que torcemos, haciéndonos aborrecer lo que amábamos antes, olvidando nuestros pecados como si no fueran hechos, y apartándolos tanto de nos que dice David: Cuanta distancia hay de donde sale el sol a donde se pone, tanto lanzó Dios nuestros pecados (Sal 102,12). Así que el derecho y el primer mirar de los ojos airados de Dios no es contra el hombre que Él crió, mas contra el pecado que nosotros hecimos. Y si algunas veces mira al hombre para lo echar a perder, es porque el hombre no le dejó ejecutar su ira contra los pecados, que Dios quería destruir; mas quiso perseverar y dar vida a los que a Él mataban, y a Dios desagradaban. Y, por tanto, justo es que su muerte quede viva, y su vida siempre muera pues que no quiso abrir la puerta al que, por amor y con amor, quería y podía matar a su muerte y darle vida», Juan DE ÁvILA, Obras completas, op. cit., vol. I, pp. 501-502.

138 Idem.

En torno al 1526, un cristiano nuevo, el humanista Juan del Castillo, perseguido por la Inquisición a causa de su «luteranismo», expresó su crítica al Santo Oficio con la misma imagen utilizada sucesivamente por Juan de Ávila: «obra de muerte», en contraposición a la vida que representaba la fe en Cristo. M. L. GioRdANo, Apologetas de la fe., op. cit., p. 153.

${ }^{139}$ San Juan DE ÁvILA, Obras completas, op. cit., vol. I, pp. 520-521.

Hispania Sacra, LXII

125, enero-junio 2010, 43-91, ISSN: 0018-215-X 
expresión «a los cuales [Cristo] fue enviado» fue modificada en la edición de 1574 así: «a los cuales predicó en propia persona». ${ }^{140}$

Poco después volvió a subrayar el concepto. Para todos los judíos que se convirtieron había sido una «grande honra» que Cristo viniera «de ellos y principalmente a ellos». ${ }^{141} \mathrm{El}$ mensaje era tan directo que también en este caso fue retocado en la edición de 1574 . Allí los gentiles aparecieron en primer plano, como principales destinatarios del Evangelio, dejando a los judíos en un calculado segundo plano. ${ }^{142}$

¿Por qué tantas peligrosas reivindicaciones, tarea notable y valiente en tiempos de la Inquisición? A un siglo de distancia del virulento ataque de García de Mora, y a más de cincuenta años de la expulsión, el argumento de la inferioridad de los judíos continuaba vigente en la lucha contra los conversos hasta el punto de exigirles rebatir esas acusaciones.

Estas reivindicaciones formaban parte además de un magisterio dirigido a muchos cristianos nuevos, como Diego Pérez de Valdivia, brillante estudiante y luego rector de la Universidad de Baeza, ${ }^{143}$ o los hermanos Loarte, y muchos otros que debieron de reconocerse en un mensaje lanzado contra «la soberbia de nuestro tiempo». 144

Entre las víctimas en los autos de fe de Sevilla contra los «luteranos» se contaban personas muy cercanas a Juan de Ávila, como el converso García Arias, apodado el «Maestro Blanco», ${ }^{145}$ prior de los jerónimos de San Isidro, unos de los focos del luteranismo hispalense. ${ }^{146}$ Sus tendencias innovadoras le habían llevado a suprimir los ayunos, las abstinencias y el culto de las imágenes; asimismo sustituyó las horas canónicas y todo tipo de rezo por la lectura de las Sagradas Escrituras y por unas charlas diarias sobre los Proverbios de Salomón. A diferencias de sus monjes, que lograron ponerse a salvo huyendo al extranjero,

140 Ibidem, p. 774.

141 Ibidem, p. 526.

142 Ibidem, p. 774: «Y Cristo así predicado es luz, entonces y ahora, para los gentiles que le quieren creer, y es luz y honra para los judíos que también quieren creer, como lo nota san Pablo, diciendo: De los cuales viene Cristo según la carne, el cual es, sobre todas las cosas, Dios bendito por todos los siglos».

143 Juan Manuel SÁnchez Gómez, «Un discípulo del P. Maestro Ávila en la Inquisición de Córdoba. El dr. Diego Pérez de Valdivia, catedrático de Baeza», Hispania, tomo IX (1949), pp. 104-134.

144 San Juan DE ÁvILA, Obras completas, op. cit., vol. I, p. 407.

145 Ávila envió una carta a García Arias desde Granada en 1538 con algunos consejos sobre la oración, en la que recomendaba también la lectura de Erasmo. San Juan DE ÁvilA, Obras completas, op. cit., vol. IV, carta n. 5, pp. 33-40.

${ }^{146}$ M. MenéndeZ y Pelayo, Historia de los Heterodoxos españoles, BAC, Madrid, 1956, vol. II, p. 86. 
él fue «relajado al brazo secular» y quemado en persona en el cuarto auto de fe del 28 de octubre de 1562.147

En 1560 fue desterrado a Córdoba el hermano de doña Sancha Carrillo, el clérigo don Pedro Fernández de Córdoba, quien se contaba también entre los discípulos de Ávila. Juan Pérez de Pineda, amigo de Egidio y de Constantino, rector del colegio de la Doctrina Cristiana de Sevilla, otro baluarte del «luteranismo» hispalense con el que estuvo relacionado Ávila, figuraba entre los relajados «in effigie», por haber huido de España, en el auto de fe de diciembre de ese mismo año. ${ }^{148}$

Hemos mencionado al más conocido de todos, el dominico Luis de Granada. Gracias a él el arzobispo de Toledo, Bartolomé de Carranza, pudo conocer el pensamiento de Juan de Ávila, como demuestran «unas notas a la exposición del salmo «Audi filia» hechas por el Mtro. Ávila» que figuraban entre los libros del arzobispo examinados en su proceso inquisitorial. ${ }^{149}$

Años antes, en 1539, desde Escalaceli, en la sierra de Córdoba, el padre Luis de Granada había enviado una carta a Carranza, que acababa de empezar un curso sobre las epístolas paulinas. El tono afectuoso de la carta se mezcla con la sutil amargura de quien contempla, sin reprimir su melancolía, la desoladora aridez espiritual de sus tiempos. En dos pinceladas Granada retrata así su época:

\begin{abstract}
«Querría saber cuál está su ánima, si llueve por allá o si es buen año, agradable y aceptable a Dios; si está harta o hambrienta. Hay razón tener desto cuidado, por estar plantada in terra deserta, invia et inaquosa, entre sauces y entre hayas, adonde los desterrados de Hierusalén pusieron silencio en sus órganos y suspendieron la música celestial. ¡Gran miseria es estar tan estragadas las letras el día de hoy, pues que hemos dexado la fuente de agua viva y hemos labrado los algibes! Pero todavía es bien que, cerrados los ojos, como quien bebe purga, trague v. r. estos tragos de amarguras por amor de Aquél que bebió hiel y vinagre en la Cruz».150
\end{abstract}

«Terra deserta, invia et inaquosa»: esto era lo quedaba del cristianismo después que los «desterrados de Jerusalén» fueran obligados a abandonar la Biblia

147 Cfr. N. Castrillo Benito, El «Reginaldo Montano»: primer libro polémico contra la Inquisición española, op. cit., pp. 69-70 y p. 139.

148 M. MenÉndez y Pelayo, Historia de los Heterodoxos, op. cit., p. 103-111.

149 San Juan DE ÁvILA, «Introducción biográfica», op. cit., vol. I, p. 185. Otra muestra de las estrechas relaciones entre Ávila y Carranza la proporciona el documento de censura de los Comentarios sobre el Catechismo Christiano del ilustre dominico. Los censores Melchor Cano y Domingo De Cuevas, creyendo haber encontrado otros textos de Carranza o muy cercanos a su ambiente, añadieron a los $\mathrm{Co}$ mentarios dos escritos que tacharon de luteranos y alumbrados. Estos eran la carta $\mathrm{n} .20 \mathrm{y}$ el Tratado del amor de Dios del padre Ávila. Cfr. Luis Sala Balust, «Una censura de Melchor Cano y de Fr. Domingo de Cuevas sobre algunos escritos del P. Mstro. Ávila», Salmanticensis, 2 (1955), pp. 677-685.

150 Álvaro HuERGA, «Fray Luis de Granada en Escalaceli. Nuevos datos para el conocimiento histórico y espiritual de su vida», Hispania, tomo X (1950), pp. 328-331.

Hispania Sacra, LXII

125, enero-junio 2010, 43-91, ISSN: 0018-215-X 
(la «fuente de agua viva»), y acallar la «música celestial» que destilaban sus instrumentos. 151

Reaccionar al silencio era sin duda una empresa ardua y arriesgada. Con todo, había un camino que podía seguirse y una tradición a la que mirar. Era importante, antes que nada, expresar una personal resistencia al esquema inquisitorial. Poder conservar la libertad de la mente implicaba volcar ese modelo: es decir, sentirse los únicos verdaderos cristianos y constructores de la Iglesia del Espíritu, según la enseñanza paulina.

En definitiva, Ávila quiso recordar que Israel había sido el primer destinatario del mensaje cristiano porque en este punto se había realizado una flagrante expropiación de la memoria, que el clima cultural de la Contrarreforma ayudó a perpetuar. ${ }^{152}$

\section{LA «CRUDA GUERRA EN EL CAMINO DE DIOS»}

Mientras enseñaba a doña Sancha Carrillo cómo «conformar nuestra voluntad con la de Dios», ${ }^{153}$ rememoraba los sufrimientos de los tiempos pasados, desde el Éxodo hasta las más recientes tribulaciones. Términos como «destierro», «atribulados», «consolados», «paciencia», «batalla», «guerra», «paz», se suceden hasta el gozoso anuncio de la llegada a una madurez espiritual largamente buscada. Se dirigía a los suyos cuando escribía triunfante: «Nuestra viña ha florecido». Y fue realmente así, pues fue el grupo de espirituales de Sevilla,

151 De eso se quejó también Fray Luis DE LEón en De los nombres de Cristo, Cátedra, Madrid, 1980, pp. 139- 140 .

152 Uno de sus efectos ha sido, hasta tiempos muy cercanos a nosotros, el de reducir la variedad de las reacciones de las comunidades hebraicas del mundo antiguo frente al cristianismo a la concepción monolítica de la «traición» o del «no reconocimiento» de Cristo. Sobra recordar cuánto este topos haya condicionado la exegesis cristiana de las Escrituras. Me limito aquí a subrayar sólo que uno de los principales problemas que San Pablo encontró en el curso de su predicación vino precisamente de las comunidades de judíos convertidos al cristianismo. Hacia estas últimas el apóstol adoptó unas decisiones realistas, como la de respetar los rituales del judaísmo, la circuncisión y la purificación. Este conformismo acomodaticio estaba pensado para no escandalizar a las comunidades de convertidos imponiendo una ruptura radical con sus antiguas costumbres judías. Obedeciendo a esta conducta de moderación, Pablo hizo circuncidar a Timoteo (Act. 16,3). Cuando el Apóstol llegó a Jerusalén, los hermanos de la comunidad cristiana de la ciudad fueron a saludarle, diciéndole: «Ya ves, hermano, cuántos miles y miles de entre los judíos han abrazado la fe, y todos son fervientes partidarios de la Ley. Pero han oído decir de ti que enseñas a todos los judíos que viven entre gentiles que se aparten de Moisés, diciéndoles que no circunciden a sus hijos ni observen las tradiciones. ¿Qué hacer, pues? Porque va a reunirse la muchedumbre al enterarse de tu venida». (Act. 21,20-23). Aconsejado por los hermanos de la comunidad de Jerusalén, Pablo aceptó de participar en sus ceremonias, purificándose con ellos y comportándose como un defensor de la Ley.

${ }^{153}$ San Juan DE ÁvILA, Obras completas, op. cit., vol. I, pp. 427-428. 
entre los cuales destacaba Constantino Ponce de la Fuente, junto con sus discípulos y estimadores, Luis de Granada y Carranza entre ellos, el laboratorio del beneficio de Cristo en España. Visto desde una perspectiva histórica, como debió verlo Juan de Ávila, se trataba del momento culminante de un largo recorrido espiritual y humano. A pesar de ser «tiempos recios», eran a la vez tiempos de plenitud para una historia de conversión que tenía un siglo y medio de vida.

Este triunfal optimismo no hizo olvidar las amenazas sobre ese brote de «nueva vida y fructífera»: «las pequeñuelas zorras, que destruyen las viñas» (Ct., 2,15). Una de ellas resultó tan difícil de vencer que algunos, «por no sufrir guerra tan cruda en el camino de Dios, lo dejan y se dan abiertamente a pecar, pensando por allí huir de ellas; o, si esto no hacen, algunos suelen venir a desesperar, por no sufrir guerra tan cruda». ${ }^{154}$ La palabra «guerra» se repite otras dos veces en la última frase.

Con esta lectura alegórica del Cantar de los Cantares, Juan de Ávila se hizo cargo de las dificultades que continuaban cerrando a los conversos el camino hacia Dios. ${ }^{155}$ Quiso también apaciguar los ánimos. A los «desesperados», veteranos de esta «guerra tan cruda», les recordaba que Dios no los había olvidado. Para todos los «quebrantados de corazón», entristecidos por el conocimiento de sus pecados o estremecidos bajo el peso de sus culpas, tenía preparada una «medicina muy más eficaz»: el «inmenso beneficio de amor como fue padecer Cristo por nos». 156

«Nuestra viña ha florecido» significaba evidentemente que los descendientes del pueblo de Israel habían llegado al umbral de «la puerta por donde el que entrare será salvo (Jn. 10,9), y la escalera por donde suben al cielo (Gen. $28,12) » .{ }^{157}$ Ellos ya pertenecían a la historia cristiana de la salvación.

154 Ibidem, pp. 428-429

155 A este propósito, tiene todo el valor de un respaldo documental el testimonio de la carta que en el octubre de 1554 el jesuita don Antonio de Córdova envió al padre Ignacio de Loyola. En ella explicaba la situación de los conversos: «(...) Me han ablado algunas personas de qualidad (...) diziendo que desean que la Compañía quitase este abuso que ai en estas partes, de hazer esta distinción y aceptión de personas, siendo en la verdad las de este linaje en las que más christiandad se halla, y á que más fácilmente se les persuade toda virtud, que á los que tienen otra opinión; porque estos ni con recebillos, ni con dexallo de recebir, se edifican, ni aun induzen á los buenos exercicios; (...) y andan tan aflixidos, que dexan algunos de boluerse al servicio de nuestro Señor, por ver que tan cerrados hallan los caminos para Dios; y aun algunos se dexan de venir á bautizar, según sé de cierto, por el mal tratamiento que les hazen.» MHSI, Ep. mixt IV, pp. 418-420. Cfr. Supra nota 132.

156 San Juan DE ÁvILA, Obras completas, op. cit., vol. I, p. 459.

157 Idem. 


\section{CONCLUSIONES}

¿Por qué Alonso y Teresa de Cartagena escribieron «en código» y por qué mantuvieron aquella discreción? La naturaleza de sus textos, así como su estilo, apunta a un lector muy bien definido. El público de su obra y la circulación en forma manuscrita, como en el caso de la Arboleda de los enfermos, acreditan su carácter de escrito «privado», dirigido a círculos y a grupos de personas concretas, para quienes los dos fueron líderes y guías espirituales.

En el caso de Alonso, la prudencia se debe al hecho de que en definitiva era un cristiano que no sólo defendió a los conversos, poniéndose públicamente a su lado con el Defensorium unitatis christianae; con sus dos otros escritos, Judica me Deus y el Oracional, los inició a «otra» experiencia cristiana. Aun respaldando abiertamente posturas de asimilación, como en su caso, un discurso de este tipo no dejaba de ser muy comprometido.

En Teresa, la adhesión a la forma del doble registro, o de la alegoría, responde a la necesidad de evitar problemas, como los que tuvo cuando entró en el convento de las Clarisas de Burgos. La mala experiencia padecida en aquella ocasión la obligaría a ser más prudente en el futuro.

El compromiso con los cánones del género consolatorio, mero pretexto para construir una ética de la paciencia, con todo el cultivo de las virtudes propias de la misma, es asumido como un cómodo e insospechable disfraz en el que envuelve su discurso.

Teresa no escribió para llenar los silencios de una plácida y abstraída vida conventual. ${ }^{158} \mathrm{Al}$ contrario, ella representaba la sociedad cultivada del Cuatrocientos que hizo de la literatura un medio de expresión política, pues la entrada de los conversos en la ciudadela cristiana requería un esfuerzo conjunto de los cristianos viejos y nuevos.

Hemos visto cómo Alonso de Cartagena volcó el antiguo concepto de «linaje» en la realidad de un nuevo pueblo, resultado de la mezcla y fusión de judíos y cristianos. He aquí expresada con equilibrio y realismo una idea del porvenir de Castilla, un proyecto de sociedad que no consiguió superar las tenaces resistencias que levantó a lo largo de los siguientes años.

$\mathrm{Su}$ habilidad fue llevar la controversia al terreno espiritual. El obispo de Burgos afirmaba sin complejos que consideraba la experiencia religiosa de los

\footnotetext{
${ }^{158}$ En cuanto a la finalidad de la obra, no comparto la opinión de Deyermond, según el cual «The Arboleda is, then, to some extent a work of auto-consolation, a variant of the widespread fifteenth-century genre of the consolatory treatise which derives ultimately from Beothius. (...). Her aim was to teach others a moral lesson that she had painfully learned and to forge for herself a weapon against adversity». Cfr. Alan DEYERMOND, ««El convento de dolençias»: the works of Teresa de Cartagena», op. cit., p. 22 y p. 24
} 
cristianos viejos de menor calidad respecto a la practicada por los judeo-conversos. A ellos, por descender del «linaje excelente» de la religión interior, les correspondería un estatus de superioridad entre los cristianos. ${ }^{159}$

Con la misma genialidad, Teresa «desordenó» las categorías mentales de todos, cristianos viejos y nuevos: el sufrimiento del converso dejó de ser «mancha» y maldición para trasformarse en signo de redención y prueba de estar en un plan de salvación divino.

La construcción de la identidad cristiana de quien procedía de linaje judío fue todo un reto. Su respaldo teológico, la concepción paulina de la fe, fue un sello duradero que desde entonces identificó toda experiencia de espiritualidad conversa. ${ }^{160} \mathrm{Su}$ expresión institucional hubiera sido una Iglesia renovada gracias a la reforma eclesiástica puesta en marcha por Hernando de Talavera, pero este proyecto se hundió, unos pocos años después, en el escenario granadino de finales del siglo XV.

Juan de Ávila sabía que, a pesar de todas las dificultades y adversidades, había nacido algo nuevo. Por eso escribía exultante: «nuestra viña ha florecido». Y efectivamente él pudo saborear el fruto de un complicado proceso en el que se habían enfrentado dos grupos sociales: los que querían integrarse y los que pusieron todo tipo de obstáculos para impedirlo. De esta tensión surgió una fenomenología religiosa que, bajo la permanente sospecha de heterodoxia, no dejó de destilar una labor creativa hasta convertirse en una «otra» Iglesia cristiana, ahora plenamente consciente de sí misma. Esta es reconocible en los aspectos comunes de las tres experiencias espirituales aquí analizadas: el iluminismo paulino, con su énfasis en la potencia de la gracia de Dios en el hombre; el uso de la alegoría como crítica encubierta a la mentalidad inquisitorial y la conciencia de estar cercado y en guerra, autentico leitmotiv literario de los tres textos estudiados.

A lo largo de todo el siglo XVI, la espiritualidad del «hombre interior» no ofreció sólo el testimonio de una experiencia literaria extraordinariamente vital. Sus intérpretes expresaron también una inquietud indomable que inspiró un pensamiento crítico hacia la ideología dominante. No sería excesivo reconocer en ello una aportación decisiva a la historia cultural de Europa.

${ }^{159}$ La conciencia que los judíos hispanos tenían de la superioridad de su linaje ya había sido intuida por A. CASTRO: «(...) Los hispanos-hebreos se sentían «fidalgos per natura», por haber sido su linaje planeado por Dios, con paternidad espiritual atestiguada por la misma palabra divina. ¿Qué mayor nobleza que la de los hijos de Israel, de Abraham?, decía en el siglo XV Juan de Lucena, amigo del Marqués de Santillana», I., De la Edad conflictiva, Taurus, Madrid, 1972, p. 45.

160 Cfr. M. L. Giordano, Apologetas de la fe, op. cit. 
Además, hay suficientes argumentos para poder afirmar que la historia de la Reforma en España está vinculada indisolublemente a la de los conversos, hasta el punto que «les cristianos viejos qui découvrent le christianisme en esprit deviennent eux aussi cristianos nuevos». ${ }^{161}$ Esta fecunda confusión de linajes queda magníficamente plasmada en la espiritualidad del beneficio de Cristo, todo un símbolo de unidad y cohesión entre cristianos que apuntaba a un nuevo modelo de sociedad.

Para que esto sea visible desde el punto de vista historiográfico es necesario descodificar el complejo entramado de reacciones defensivas de los cristianos nuevos en los tiempos de la persecución. Afloraría, entonces, un mundo espiritual hasta ahora en gran parte sepultado, bajo el peso de un modelo interpretativo que eterniza la visión menedez pelayana de la España religiosa.

De todas formas, los datos que de momento están disponibles permiten comprobar la estrecha relación entre cristianismo interior y conversos. He aquí un punto de arranque inamovible para una nueva definición de Reforma, extraordinariamente precoz respecto a los tiempos europeos y deudora del mundo espiritual paulino del siglo XV.

${ }^{161}$ Marcel BatAILLON, «L'espagne religieuse dans son histoire», op. cit., p. 24. 